This item was submitted to Loughborough's Research Repository by the author.

Items in Figshare are protected by copyright, with all rights reserved, unless otherwise indicated.

\title{
Working loose: A response to "Donald Trump shoots the match" by Sharon Mazer
}

PLEASE CITE THE PUBLISHED VERSION

https://doi.org/10.1162/DRAM_c_00764

\section{PUBLISHER}

Massachusetts Institute of Technology Press (c) New York University and the Massachusetts Institute of Technology

\section{VERSION}

VoR (Version of Record)

\section{PUBLISHER STATEMENT}

This work is made available according to the conditions of the Creative Commons Attribution-NonCommercialNoDerivatives 4.0 International (CC BY-NC-ND 4.0) licence. Full details of this licence are available at: https://creativecommons.org/licenses/by-nc-nd/4.0/

\section{LICENCE}

CC BY-NC-ND 4.0

\section{REPOSITORY RECORD}

Warden, Claire, Broderick Chow, and Eero Laine. 2019. "Working Loose: A Response to "donald Trump Shoots the Match" by Sharon Mazer". figshare. https://hdl.handle.net/2134/34212. 


\title{
Donald Trump Shoots the Match ${ }^{1}$
}

\author{
Sharon Mazer
}

The day I realized it can be smart to be shallow was, for me, a deep experience.

—Donald J. Trump (2004; in Remnick 2017:19)

I don't care if it's real or not. Kill him! Kill him! ${ }^{2}$

He's currently President of the USA, but a scant 10 years ago, Donald Trump stepped into the squared circle, facing off against WWE owner and quintessential heel Mr. McMahon ${ }^{3}$ in the "Battle of the Billionaires" (WrestleMania XXIII). The stakes were high. The loser would have his head shaved by the winner. (Spoiler alert: Trump won.) Both Trump and McMahon kept their suits on-oversized, with exceptionally long ties-in a way that made their heads appear to hover, disproportionately small, over their bulky (Trump) and bulked up (McMahon) bodies. As avatars of capitalist, patriarchal power, they left the heavy lifting to the gleamingly exposed, hypermasculinist bodies of their pro-wrestler surrogates. McMahon performed an expert heel turn: a craven villain, egging the audience to taunt him as a clueless, elitist frontman as he did the job of casting Trump as an (unlikely) babyface, the crowd's champion. For his part, Trump seemed more mark than smart. Where McMahon and the other wrestlers were working around him, like ham actors in an outsized play, Trump was shooting the match: that is, not so much acting naturally as neglecting to act at all. He soaked up the cheers, stalked the ring, took a fall, threw a sucker punch, and claimed victory as if he (and he alone) had fought the good fight (WWE 2013b).

Professional wrestling makes a show of American values. The bodies are huge (“yuge!"), the hyperbole is excessive, and kayfabe (the con) rules. ${ }^{4}$ As Roland Barthes observed over a half century ago:

The public is completely uninterested in knowing whether the contest is rigged or not, and rightly so; it abandons itself to the primary virtue of the spectacle, which is to abolish all motives and consequences: what matters is not what it thinks but what it sees. $(1972: 15)$

Wrestling is about heat, not truth. It's never a fair fight. The guy with the money decides who wins, who loses, and on what terms. The audience knows this and plays along regardless. These are the people who voted for Trump. This is their, and his, ethos. This is how, having converted his fans into voters, he is running the presidential show: the unreal violence of the game now the all too real brutality of the current regime.

1. This article was first posted on 24 August 2017 on Facebook, then on 7 September 2017 on the TDR/ MIT website and has been updated for this final version.-Ed.

2. Overheard, more than once, at various professional wrestling events.

3. The thinly veiled wrestling persona of WWE owner, Vince McMahon.

4. Kayfabe is a concept central to professional wrestling, a legacy of wrestling's sideshow origins in relation to the con artistry prevalent in that milieu. It's actually not easy to define, but in general is understood to be the act of maintaining the façade of the real while carrying on with the fakery of the game. 
The world of professional wrestling has come to be embodied in the political arena in the figure of Donald Trump, who has been part of the game for decades and also, most importantly, in the fans who continue to rally for him. ${ }^{5}$ Spectacle trumps truth. Paradoxically, to them, he offers an image of the real deal, someone whose performance breaks with convention, in the White House as in the squared circle. It's not that he is unable to act presidential, he says: "Presidential's easy" (GB 2016). It's that he knows that we know that the presidency is an act-a fact he demonstrated on the campaign trail by parodying himself performing the role, a mockery of presidential decorum, to appreciative laughter (see also Martin and Peters 2016).

Wrestling's capacity to generate heat is something toward which scholars-myself included — can be seen at times to gravitate with almost unseemly alacrity. Since the early stages of Trump's campaign, there have been numerous, ostensibly authoritative discussions of kayfabe in both the academic and the popular press, including Nick Rogers in the New York Times (2017) and R. Tyson Smith in the Huffington Post (2017). Some have done their homework. For example, Smith is the author of the ethnography Fighting for Recognition: Identity, Masculinity, and the Act of Violence in Professional Wrestling (2014). Others, like Rogers, seem to have helicoptered in, picked up a bit of the lingo, and skated on a few of the basics to offer the public some relatively cheap shots. Like wrestlers, they seem to be jockeying for position, announcing themselves in hopes of jobbing up the food chain.

I blame myself. It was my first article, for $T D R$ in 1990, and the subsequent book in 1998-Professional Wrestling: Sport and Spectacle — that set the stage for what appears now to be a burgeoning field of professional wrestling studies: books, articles, dissertations and theses, courses and conferences worldwide- there's even a new professional wrestling studies association. I was criticized then on one side for appearing to turn a blind eye to pro wrestling's less savory social and political realities, and on the other for reading too much into the game. ${ }^{6}$ Having reflected more generally on what I've learned since then, ringside and beyond, in "The Game of Life" (2017), an essay that takes only a glancing look at Trump's campaign, here I want to return to the time when both the World Wrestling Federation (WWF) and Donald Trump dominated the tabloids, to see how Trump's success with the voters in 2016, along with the ongoing presidential drama, might have been shaped by his association with the game.

\section{What the World Is Watching!}

It was the late 1980s when, at Richard Schechner's suggestion, I wandered away from the rarified bubble of Columbia University and the dissertation I was writing on Middle English drama into the Unpredictable Johnny Rodz School of Professional Wrestling at Gleason's Gym (Brooklyn,

5. The WWE has entered the political arena more directly in the figure of Linda McMahon, who, as Trump's appointee, now leads the Small Business Administration; like many of Trump's other appointments, there is an aspect of setting the cat amongst the pigeons in having the wife of the owner of one of America's biggest (if not the most exploitative) business ventures looking after the little guy.

6. See, for example, Toby Miller's spewing review of my book in which he complains of my failure to criticize the "political economy of the sport" (2001:175). Or any of the more negative reviews on Amazon. Or for that matter, Stone Cold Steve Austin's succinct response to a quote from the book: "bullshit" (in Heath 1998-1999).

7. This was the WWF's banner through most of the 1980s and into the 1990 s. 
NY). ${ }^{8}$ The WWF was in its first ascendance. Vince McMahon had taken over the family business from his father ${ }^{9}$ and, capitalizing on a savvy mix of syndicated and cable television productions (both free-to-air and pay-per-view), was industriously transforming what had been a regional promotion into the multiplatform juggernaut that is known now as the WWE (World Wrestling Entertainment). The headliners were Hulk Hogan and Macho Man Randy Savage, who as the "Mega Powers" were masterfully building heat in an elaborately staged escalation of their fight over the affections of the "lovely" Miss Elizabeth. The star-studded line-up in those years included Ravishing Rick Rude, Rowdy Roddy Piper, the Ultimate Warrior, Hacksaw Jim Duggan, Big Boss Man, Jake "the Snake" Roberts, Andre the Giant, Mr. Perfect, Jesse "the Body" Ventura, ${ }^{10}$ and brothers Owen and Bret Hart-all of them larger than life, "monsters" in the parlance.

McMahon and Trump were sharing the spotlight and doing business together even then. Both WrestleMania IV (1988) and WrestleMania V (1989) set up shop in Trump Plaza (Atlantic City). In the lead-up to WrestleMania $V$, Trump loomed large in a promotional interview between Hulk Hogan and "Mean" Gene Okerlund. There was the Hulk, snarling at Savage through the camera:

Just like Donald Trump, Macho Man, I hope you're ready, brother, because Donald Trump has questions in his own mind. He sent a whole team of seismatologists [sic] out here to check the foundation of the Trump Towers, because when the Megapowers explode on the launching pad, brother, as we erupt over the whole Atlantic City, he was worried about the foundation, he was worried that the thousands of people in the arenas might become unseated and swallowed by the earth. Donald Trump, don't worry about my Hulkamaniacs. They're survivors. They're ready. (TheOneWWEGuy 2010)

In hindsight, the alignment of Hulk Hogan with Donald Trump in 1989 may have done as much to set the stage for Trump's later performances as a populist as it did for the Hulk's own popular following. We see Hulk Hogan at his peak as a hero of the people. His impossibly muscular torso is improbably bronzed in a way that makes Trump's famously fake tan appear aspirational; it gleams impressively in the studio lights as he towers over "Mean" Gene, the WWF's long-running commentator-himself not a small man except when standing in Hogan's immense shadow. (Or is Hogan standing on a box?) Trump doesn't have to be seen to be visible in the wrestling imaginary. Hogan's stature is built on the idea that he stands for the people-the "Hulkamaniacs"-whose fervor fuels his victories. His fictionalization of Donald Trump's concerns - sending in the "seismatologists" - may be an absurd flight of fancy, but it also implants Trump into the narrative as a decent enough guy who shares Hogan's concern for the safety of the Hulkamaniacs: if not a fully formed babyface, in wrestling terms, then certainly not a heel.

8. Johnny and his school are still going strong, it seems. See "The World of Unpredictable Wrestling" (https://wuwonline.com) and Mazer (1990).

9. Like circus, or indeed theatre families, professional wrestling is often a transgenerational enterprise. McMahon's father, in fact, inherited the promotion from his own father, and McMahon's son, Shane, who makes a dramatic appearance in the "Battle of the Billionaires" as a fake referee in a failed attempt to throw the match toward his dad, has been working his way to the top for the past decade or more.

10. After retiring from wrestling, Jesse Ventura went on to become Governor of Minnesota from 1999-2003. 
In the world of wrestling circa 1989, that is, Trump appears as a surprisingly genial "suit," an odd oasis of seemliness surrounded by preposterousness. It is in this guise also that he turns up at WrestleMania $V$ for a ringside interview with WWF commentator Sean Mooney.

MOONEY: I'm joining Donald J. Trump, the illustrious Donald J. Trump. Mr. Trump, this is the second WrestleMania you have hosted in a row. Can you give us some idea of what an event of this magnitude means not only to Atlantic City but to the Trump Organization?

TRUMP: Well, it's brought people from thousands of miles away. It's been fantastic. It's been unbelievable - the traffic, the numbers of people that wanted to be here-we're really honored to be here and honored that you folks joined us. It's a great honor. (KrisAnderson97 2016)

The braggadocio is relatively subdued in this exchange, its tone conversational, rather than bombastic - unlike Trump's repeated grandstanding as he continues to lie about the number of people on the Mall during the 2017 Presidential inauguration, or even the combative display in the ring in 2007. Trump is a salesman, doing the job, almost perfunctory in promoting his casinos as much as himself. Mooney asks, "Have the casinos been busy?" Trump responds: “They've been packed. The whole town is packed. It's been a real boom [sic] to the town. It's been just a great thing, and an unbelievable event. Everyone's excited. We're all enjoying ourselves." Mooney makes a half-hearted joke about losing money in the casino, then closes with: "While Macho Man Randy Savage and Hulk Hogan still have to worry about winning, it seems Donald J. Trump already has." Trump is two years away from declaring bankruptcy on his Atlantic City casinos. For the moment, he is indeed a winner. Being too big to fail, he can't really lose.

\section{The Cooked and the Raw ${ }^{11}$}

The exchange between Trump and Mooney sounds canned in contrast to the incipient brawl in the ring, an almost quiescent break between the overwrought give-and-take of the commentators and the hyperphysical swinging and flinging of the wrestlers. There's a reason for that. Professional wrestling is a kind of "affect factory" (Ridout and Schneider 2012:6). ${ }^{12}$ Since the fight is fixed, winning and losing are, in effect, beside the point. Success is marked by the degree of heat generated. Wrestlers who stir the crowds get booked; they get choice spots on the card, are featured on television and in other media, and are called "superstars." From the promoter's perspective, it's simple: galvanized fans buy tickets, pay-per-view events, and merchandise. Fandom is contagious. In their often feverish debates about what's happening and how it's being constructed for their consumption, fans solidify their attachments to the game and amplify the promoter's pitches for audiences. ${ }^{13}$

11. With apologies to Claude Lévi-Strauss.

12. On the prevalence of affect over ideology in political campaigns, see Iyengar et al. (2012).

13. With the emergence of the World Wide Web-coincidently as the WWF was coming to dominate the field - the circulation of fan culture escalated both in pitch and range. But it was ever so. Wrestling promoters have always been keen adopters of new technologies and media, starting with first radio and then television in the early 20th century, and now the internet, beginning in the early 1990s when the first widely popular lists, discussion groups for wrestling fans, took off. 
Metaphoric heat works like the real deal. It's easy to build up a tolerance. When theaction flattens out, the spectators chant "BORRR-RRRING." But many dips and lulls in the match are intentionally grafted into its kinesthetic arc. They're a way of "cooling the mark out," in Erving Goffman's terms ([1952] 1997), serving the greater con. The cool interludes—a series of holds that seem to go on too long, a debate by the commentators on the sidelines that seems like too much talk not enough knockabout-reset the stage and make the punters even more eager for what comes next. They lower the temperature as it were, in anticipation of a spike, so that the heat can be fully felt as such. This is, I think, the role Trump played ringside with Sean Mooney in 1989: something more than filler, but less than entertaining, as much to make us impatient for the next round as to promote the Trump brand.

By the end of the 1980s - that is, before The Apprentice but certainly at a time when his political ambitions were percolating under the surface-Trump's persona as a celebrity businessman was already well established in the world of wrestling. His appearances in the WWF offered a platform from which he could see his image broadcast far beyond New York City. There's nothing much of the bully boy in his appearance ringside, quite the opposite, and he's more coherent than Sean Mooney, whose performance is notably stumbling. While we're waiting for the main event- the hotly anticipated grudge match between Hogan and Savage ("The Megapowers Explode!")-Trump appears as the epitome of cool, stationed calmly between the boisterous fans and the hyperbolic violence of the wrestlers. A babyface, not a heel, he's presented to the audience as a successful businessman. The con of his casinos-fleecing both the punters and, as it surfaced only a short while later, also contractors and creditors, big and small-appears mild, almost commonplace against the hypermasculinist blustering wrestling game. In this sense, the pairing of Trump with the WWF can be seen to have effected a kind of reciprocal legitimation, creating a closed loop. No matter where one looked, the con was on.

Here is where I admit that, from where I was, sitting safely in the balcony of the Beacon Theatre on New York City's Upper West Side, watching the event on closed-circuit television, I don't remember Trump's appearance on that day. What I do remember, vividly, viscerally, was the way the room reacted when Hulk Hogan won the championship belt, everyone jumping, dancing, and shrieking, mimicking Hogan's gesture in raising the belt over his head (sometimes with their plastic souvenir belts, sometimes empty-handed), and taking so many photos of the screen that the flashes wiped out the image entirely, making it a blank white canvas. The Beacon was packed, as were equivalent theatres across the USA, sold out in only a day or two at a time when you had to take your chances on the phone dialing an 800 number that was invariably busy, or lining up at the box office to buy tickets to see the event on a big screen. This was an audience that relished the opportunity to share the thrill of communal spectating, even if the show itself was canned. They were a diverse mob: young people and families, older men and women, black and white, Asian and Hispanic, gay and straight, professional and blue collar, dressed down and dressed up for the closed circuit broadcast at the Beacon in the same way as live audiences were, in my experiences, at Madison Square Garden, the Manhattan Center, and the Meadowlands Arena where I regularly attended matches from 1988 to 1994. So much for the conventional wisdom about wrestling fans-like Trump voters-just being working-class schlubs and their unwashed teenage sons. 


\section{It's All a Matter of Taste, and Yours Is Rotten ${ }^{14}$}

Media scholar Henry Jenkins observed in Textual Poachers, his landmark study of fan culture, that

the term fan $[. .$.$] never fully escaped its earlier connotations of religious and political$ zealotry, false beliefs, orgiastic excess, possession, and madness, connotations that seem to be at the heart of many of the representations of fans in contemporary discourse. (1992:12)

Jenkins recognizes something uncool in the social construction of the fan: a problem of class as well as taste that we can see playing out in professional wrestling as elsewhere. He says:

[T] he fan still constitutes a scandalous category of contemporary culture, one alternately the target of ridicule and anxiety, of dread and desire. Whether viewed as a religious fanatic, a psychopathic killer, a neurotic fantasist, or a lust-crazed groupie, the fan remains a "fanatic" or false worshipper, whose interests are fundamentally alien to the realm of "normal" cultural experience and whose mentality is dangerously out of touch with reality. (1992:15)

In "Never Trust a Snake': WWF Wrestling as Masculine Melodrama," first published in 1997 and updated in 2005, Jenkins notes the diversity of wrestling audiences- "children, young and older women, gays, etc." (2005:36) — but his primary preoccupation is with

the complex interplay of affect, masculinity, and class, issues which surface in both the formal and the thematic features of televised wrestling, in its characteristic narrative structure(s), its audience address, its treatment of male bonding, and its appeal to populist imagery. (2005:36)

While a fan, to some degree, Jenkins is not blind to wrestling's ideological underpinnings. "The core myth of WWF wrestling is a fascistic one," he says:

ultimately, might makes right; moral authority is linked directly to the possession of physical strength, while evil operates through stealth and craftiness (mental rather than physical sources of power). The appeal of such a myth to a working-class audience should be obvious. In the realm of their everyday experience, strength often gets subordinated into alienated labor. Powerful bodies become the means of their economic exploitation rather than a resource for bettering their lot. (2005:41)

Professional wrestling is, above all, about men and masculinity, ${ }^{15}$ about what it takes to remain upright in an unfair fight. For Jenkins:

Melodramatic wrestling allows working-class men to confront their own feelings of vulnerability, their own frustrations at a world which promises them patriarchal

14. One of my Jewish mother's favorite sayings.

15. Even when women are wrestling, the subject is men and masculinity—something I've discussed at length in Professional Wrestling: Sport and Spectacle (1998). 
authority but which is experienced through relations of economic subordination. Gender identities are most rigidly policed in working-class male culture, since unable to act as men, they are forced to act like men, with a failure to assume the proper role the source of added humiliation. WWF wrestling offers a utopian alternative to the situation, allowing a movement from victimization toward mastery. (2005:42-43)

In the end, Jenkins sounds an optimistic note that appears cautionary in retrospect:

In short, wrestling embodies the fundamental contradictions of the American populist tradition. The politics of WWF wrestling is punch-drunk and rambunctious, yet it builds upon authentic anger and frustrations which we cannot ignore if we want to understand the state of contemporary American culture. Wrestling makes you want to shout, and perhaps we have had too much silence. (2005:64)

For my part, when I think of the fans I've sat with at matches over the years I'm struck again by the ways their personae and performances both meet and complicate the clichés. Professional wrestling is a vulgar performance practice - at once low and populist - with deep roots in the carnival sideshow. Fans are suckers, outsiders say, because they don't know, or don't care, that the fight is fixed. Like the wrestlers, that is, they're crude and rude. The whole thing is in such bad taste, even to admit to liking wrestling is to mark oneself as low class. Funny thing, though: from where I sit, wrestling fans are not at all unlike opera audiences. ${ }^{16}$ Whether slobs or snobs (Isenberg 2016:236), both groups dress for show; love to display expertise in knowing the players and the score; are passionate, if not fanatical, in expressing their approval or disapproval from one beat to the next; and stage themselves as insiders against roughly defined outsiders. It is possible, class conceits aside, that the line between grand and grandiose is not well defined after all-especially for those of us who make a habit of crossing over.

\section{These Are My People}

Sitting in the cheap seats at Madison Square Garden 20 or so years ago, and even more recently, as when I joined the fans ringside in the Papunui High School gym on the other side of the world, in Christchurch, New Zealand, ${ }^{17}$ my reflexive repulsion has almost instantly been met with an equally reflexive moment of recognition: these are my people. I grew up with these people, or people very much like them, in the Mohawk Valley a dozen or so miles outside Springfield, Oregon, itself a depressive, small-town cousin of Eugene, the relatively cosmopolitan, small city that hosts the University of Oregon across the river. The Mohawk Elementary School, where I started first grade, had only one room but was provisionally divided into two areas to accommodate the last wave of the baby boom, perhaps as many as 30 students, at the beginning of the 1960s. It was across from the Mohawk General Store, ${ }^{18}$ and around a slight bend in the road from the church. Most of the parents worked in the logging business,

16. I am not alone in this view. See "Skip the Opera. Go See Some Pro Wrestling," a New York Times OpDoc by Tim Grant that appeared while this essay was between drafts (2017).

17. I was there to see a local promotional event, "NWA Convergence," research for "The Game of Life" (Mazer 2017).

18. The Mohawk General Store now has its own Facebook page. See https://www.facebook.com/mohawkgeneral. 
directly or indirectly, for Weyerhaeuser or Georgia-Pacific. Whenever the mills closed-fire hazard in the forests, strikes, or economic downturns-whole families would appear in the bean fields, working alongside teenagers (myself included) for three cents a pound (an extra quarter cent bonus if one stuck out the six or seven week season). On a good day, I remember I could top 100 pounds; one year I bought a transistor radio, in another a portable record player and two or three records with what I saved. Most were there for grocery money. Such stopgaps have mostly disappeared. Even then the fields were being converted from pole to bush beans, which are more readily harvested by machines.

My classmates were fervent, fundamentalist Christian believers of one sort or another, mostly Baptists and Mormons. Many were not allowed to dance; some didn't have Christmas trees or Easter eggs because such things were pagan. Catholics were not real Christians. Jewish people were impossibly foreign. ${ }^{19}$ The " $n$ " word was part of the lingua franca, even though no one in my valley had met a black person. The " $\mathrm{f}$ " word, too, was a frequent term of abuse, even though no one had knowingly met a gay person..$^{20}$ They might not have been wrestling fans then, although my guess is that with the expansion of access to television from the two channels we could get in the 1960s, many of them are now keeping up with the WWE alongside their favorite Christian broadcast channels and Fox TV. Times have changed.

Or have they? At the end of 2015, I took advantage of the ASTR (American Society for Theatre Research) conference's Portland location to take my daughter on a tour of my childhood turf, about 100 miles from the big city. Driving across the river into the valley, I gasped - a full body spasm. I'd been prepared for radical change, to see fields of new houses, strip malls, and other signs of suburban sprawl: progress. But it was the same as it ever was. The three roads leading off the bridge carved routes alongside tributaries to the McKenzie River, down the middle and to each side of the valley, surrounded by hills still more brown than green, even in November; greying houses were still scattered at odd intervals, set into small patches of lawn with fenced fields and outbuildings—not farms per se, but each with its own assortment of farm animals and implements in a state of perpetual decay. My sense of dislocation was profound. I was simultaneously 16 and almost 60, at home and a stranger, thrown back 40 years and forced to be present in the moment with my daughter at the same time. The general store and the church and my first school (converted to a private home in the late 1960s) were right where I left them. The no-longer-new, still tiny (four rooms surrounding a library) elementary school, to which we had all been shifted just before JFK's assassination in 1963, was there too, albeit under new management as the Willamette Leadership Academy, according to their website: "a military style charter school, which provides academic, social, and emotional instruction to middle and high school students (cadets)" (Willamette Leadership Academy n.d.).

19. I "came out" as a Jewish person in high school, when we put on The Diary of Anne Frank, to a mixed response-some envy for having a distinctive identity attached to the tragedy we were learning about (it was 1971), others with odd taunts. Nothing major, just the ambivalence of difference being played out on a minor scale.

20. A few years ago, an old high school friend caught up with me on Facebook. On his page, his children were proclaiming their pride in him for his courage in coming out in the face of the Mormon Church's renewed hostilities on that front. 
We did a few circles in the school parking lot where my father taught me to drive 45 years ago, then went back down the road to look for my childhood home, along the banks of the Mohawk River. After some confusion, we came to a stop by an enormous electrified (so the sign said) chain-link and plywood fence. Peering through a small gap in the gate, nonetheless, we could see the house, cut off from the road, run down, with refrigerators and other odd appliances lining its outside walls, and a couple of pickup trucks parked on the muddy drive. Next to us were the crumbling remnants of a low stone wall; my father had spent a summer going up river for the stones and setting them without mortar, New England style, in homage to his childhood in East Stroudsburg, Pennsylvania. That was what remained. None of the grace, no half-acre of vegetable garden, no horses or sheep in the pastures, no flowers in the window boxes-no window boxes-no sign that any at home.

The repurposing of my elementary school and the degradation of my old home were anomalies in a landscape that otherwise seemed to have been temporally sidelined. Aside from the satellite dishes, there was little to suggest a connection between the people living there and the wider world. This was my childhood, encircled by families that, in the early part of the 20th century had left behind failed farms in more eastern states, traveling like the Joads in John Steinbeck's Grapes of Wrath (1939) to find (unlike the Joads, perhaps) this fertile valley with work to be done in the forests and mills, enough to get by, if not to prosper. Many if not most of the kids I grew up with have raised their own families and retired there, their children's families almost certainly close by, repeating the cycle. Where else could they have gone?

My parents had made the same east-to-west journey. Unlike the Joads and their kin, however, my mother wanted to escape the claustrophobic confines of her Orthodox Jewish upbringing in Long Beach, New York, and my father, in addition to wanting to please her, loved the land and hoped to make himself at home much as he had been in the colony of artists, musicians, and intellectuals of his early years. ${ }^{21}$ They never quite reconciled the distance between their idealism - nature as spiritual, intellectual, and creative incubator-and the realities on the ground. My struggle to comprehend how Trump could have seduced so many voters is complicated by my fascination with professional wrestling, which in turn has a great deal to do with making sense of an upbringing on the margins of a community that would have gravitated toward his presidential candidacy and who will most likely continue to support him, heedless of the cost.

21. His father started life as a shtetl Jew; my grandfather's greatest regret (aside from the premature death of my grandmother in 1936) was having been diverted into vocational training as a linotype setter instead of finishing high school and going on to university in New Haven, Connecticut, where he grew up. Having settled in East Stroudsburg, PA, and inspired by Frank Lloyd Wright, he taught himself to design and build houses around a lake he and my father had reclaimed from swampland, and he was, in his later years, a poet and playwright. My father's mother counted the first mayor of Seattle, the founders of Oberlin College, and Benjamin Franklin among her ancestors. East Stroudsburg was a summer retreat for artists and musicians; growing up, my father knew the Gershwins and my cousins recently shared memories of being sent to bed before Nina Simone sang, creeping back down the stairs to listen. 


\section{It's a Doggie Doggie World ${ }^{22}$}

The assumption that Trump voters, like wrestling fans, are predominantly white trash is pervasive, and like many assumptions, it has some basis in fact. It would be more to the point, however, to say that white trash values-of the sort Nancy Isenberg identifies in White Trash: The 400-Year Untold History of Class in America (2016) - have seeped into the wider American culture as performed both in the squared circle and in the White House. Like an outsized, populist genre of mimetic theatre, professional wrestling reflects, conventionalizes, and amplifies performances of everyday life, in particular, simulating the nationalist and social conflicts we see on television and in other media.

Isenberg tells us that "not only did Americans not abandon their desire for class distinctions, they repeatedly reinvented class distinctions" (2016:310). She is not quite anticipating Trump's presidency; rather she seems to be explaining the struggles of the Clinton campaign to come to terms with the "bread and circuses" approach to politics:

American democracy has never accorded all the people a meaningful voice. The masses have been given symbols instead, and they are often empty symbols. Nation-states traditionally rely on the fiction that a head of state can represent the body of the people and stand in as their proxy: in the American version, the president must appeal broadly to shared values that mask the existence of deep class divisions. Even when this strategy works, though, unity comes at the price of perpetuating ideological deception. (2016:310-11)

Isenberg is, of course, echoing a fair bit of conventional wisdom in these recognitions. But it is worth hearing her out, especially as her book turns back toward the question of how the current state of political affairs has been fueled by energies equivalent, and even directly connected, to professional wrestling. It's a dog eat dog world; better to root for the top dog, even if he's a cur, than to be eaten. In Isenberg's words:

Instead of a thoroughgoing democracy, Americans have settled for democratic stagecraft: high-sounding rhetoric, magnified, and political leaders dressing down at barbeques or heading out to hunt game. They are seen wearing blue jeans, camouflage, cowboy hats, and Bubba caps, all in an effort to come across as ordinary people. But presidents and other national politicians are anything but ordinary people after they are elected. Disguising that fact is the real camouflage that distorts the actual class nature of state power. (2016:311)

Isenberg's carefully wrought history of white trash America does more than offer a long-overdue perspective on the lives of the people who surrounded and informed my childhood view of the world. She shows how holding these people - my people, and those like them across the USAjust at the edge of material and spiritual poverty, anxious and precarious, but hanging on, has served to sustain the status quo for 400 years. In this light, the 2016 election might best be

22. A mishearing of "dog eat dog" that has stuck with me: how Johnny Rodz used, in rapid shifts between Puerto Rican Spanish and New York City English, to explain the game to new wrestlers, and the title of my first article for TDR (1990). 
viewed as a kind of grudge match, part of a long-running cycle in which the heat generated by the campaign, played to enrage, trumped any more rational debate.

In his postelection preface to Angry White Men: American Masculinity and the End of an Era, Michael Kimmel says the fight is "less about being white or male [...] than about being angry." ${ }^{23}$ For Kimmel, "Populism is not a theory, an ideology: it's an emotion. And the emotion is righteous indignation that the government is screwing 'us"' (2016:2). The fix is in, but the feelings are real, even if the facts are not:

The downwardly mobile lower middle class bought into the American Dream. They are true believers. To hear them tell it, if they worked hard, played by the rules and paid their taxes, they, like their fathers and grandfathers before them, could buy a home and provide for a family. (Actually, they just needed to show up. They worked, yes, but on an uneven playing field.) But as I learned interviewing many of these men, that Dream became a nightmare of downsizing, job loss, outsourcing, plant closings, closing the $\mathrm{Ma}$ and $\mathrm{Pa}$ store when Wal-Mart moved in, losing the family farm. These men feel like they are seen as failures; they are humiliated — and that humiliation is the source of their rage. (2-3)

Like Isenberg, Kimmel zeroes in on the paradox that these "angry white men" (whether "white trash" or not) focus their rage downwards- towards persons of color, women, sexual minorities, and immigrants - rather than upwards at the more privileged white men who both exploit and condescend to them. Their "aggrieved entitlement" is, Kimmel says, "nostalgic, pessimistic, reactionary" (4). They are the real men, the men "who built this country and who, in their eyes, are this country" (1).

Sounds rather like Hulk Hogan in his heyday, doesn't it? The same bluster, the world divided into winners and losers, riding the emotional wave that comes with being on the mat but rising up, always, rising to the cheers of those who believe against all evidence to the contrary, that pushing back against defeat is what real men do. The thrill of victory is fleeting, in life as in wrestling, and only properly felt against the threat of losing out. Sounds like Trump as well, whom Arlie Russell Hochschild calls an "emotions candidate" (2016:225). Hochschild turns to Trump near the end of her book, Strangers in Their Own Land, which was written during the lead-up to the election:

The source of the awe and excitement isn't simply Trump himself; it is the unity of the great crowd of strangers gathered around him. If the rally itself could speak, it would say, "We are a majority!" Added to that is a potent promise- to be lifted up from bitterness, despair, depression. The "movement," as Trump has increasingly called his campaign, acts as a great antidepressant. Like other leaders promising rescue, Trump evokes a moral consciousness. But what he gives participants, emotionally speaking, is an ecstatic high. (2016:226)

She looks to the "costumes, hats, signs, and symbols" for the way they affirm unity and create a sense of "a larger rising tide" (226). It is the "elation" itself that is addictive, she says, a

23. Many thanks to Michael Kimmel for providing a preview of this preface, dated December 2016 (see also Kimmel 2013; Faludi 1999). 
giddy, validating release [that] produced a kind of "high" that felt good. And of course people wanted to feel good. The desire to hold on to this elation became a matter of emotional self-interest. Many liberal analysts-myself included—have tended to focus on economic interest. [...] And while economic self-interest is never entirely absent, what I discovered was the profound importance of emotional self-interest-a giddy release from the feeling of being a stranger in one's own land. (2016:228)

That is, Trump's fans go to his rallies the way wrestling fans go to the arena: to feel the heat that comes from feeling one with the crowd, not necessarily to be winners themselves, but in cheering the winner and jeering the loser, to be on the side of righteousness. That the game is fixed is a given. It's too hard—-too "complicated" as Trump says—impossible, even, to surmount the invisible, powerful forces that keep them down. But it feels good to be right.

Central to Hochschild's ethnography of the people in Louisiana's backwaters is a casting into professional wrestler-esque types: the "Team Player" (or "Loyalist"), the "Worshipper," and the "Cowboy":

Each kind of person expresses the value of endurance and expresses a capacity for it. Each attaches an aspect of self to this heroism. The Team Loyalist accomplishes a team goal, supporting the Republican Party. The Worshipper sacrifices a strong wish. The Cowboy affirms a fearless self. (2016:155)

Each becomes a hero, that is, in what Hochschild calls "a deep story self": his or her own social drama-a way of being an "us" against a "them" that is no less oppressive for not being the true source of the problem. Cast as losers, they risk little in siding with the winner.

The stories Hochschild tells, the history Isenberg presents, the rage Kimmel analyzes, my own childhood memories and my encounters ringside (and elsewhere) converge as an American dreamlike narrative of lifelong yearnings and life losses, of prevarication in the face of precarity, the sort of "cruel optimism" that Lauren Berlant so eloquently identifies as occurring when "something you desire is actually an obstacle to your flourishing" (2011:1). Berlant talks about "the attrition of a fantasy, a collectively invested form of life, the good life" (2011:11), and observes "the cruelty of normative optimism and the changing meanings of mobility in the global capitalist sense" (2011:19). We can see cruel optimism at play in some way in Trump's electionas an extreme version of be-careful-what-you-wish-for, and also as the news cycles between hope that he's become "presidential" and despair when he reverts to form. We also see it in professional wrestling, when the fans vent their rage at the unfairness of a world in which the heel wins by cheating, especially when the heel wins because the referee has turned his back at an inopportune moment or, worst of all, when he is seen to make a deal with the devil-the heel or the promoter - to throw the match. We see it also in the masochistic performance of the babyface, his performance of resolution no matter the pain and suffering inflicted against him running counter to the fakery and chicanery of the heel. As Roland Barthes observed: "in wrestling, a man down is exaggeratedly so, filling the spectators' entire field of vision with the intolerable spectacle of his powerlessness" (1972:16).

Hulk Hogan's success, his megastardom, in the 1980s and '90s was built in large part on the way he would fight to the bitter (almost) end. Collapsed on the mat, the referee counting him out-"one, two, three, four..."- the fans screaming and pleading, pounding and chanting 
for him, Hogan would begin to shake, first an arm, then his whole body, as the force of his Hulkamaniacs lifted him to triumph against all odds. We didn't care if it was real or not. We felt his pain, and were moved by the kinesthetics of his revival, the pleasures peculiar to aligning ourselves with his surge to victory. Likewise, there is some cold comfort in feeling Trump's pain - as when he complains about being subject to a "witch hunt" or wails that no president has ever had it so bad—or laughing along with him as when he tweeted a video of himself pounding McMahon, but with his opponent's face supplanted by the CNN logo (Grynbaum 2017). Such performances put his supporters back into play, cheering him on and pushing back against the "fake media" and elites. That they are doomed to disillusionment makes their resolution all the more profoundly meaningful. Whether he betrays their faith or falls from grace (or both), they will see their conviction that the system is corrupt confirmed. The ebb and flow of despair and elation are all.

\section{Losers}

When Donald Trump stepped into the ring in 2007, he was a bona fide celebrity. His internationally recognizable persona as a billionaire businessman was already inflated by The Apprentice, and his signature entrance music ("money money money money"24) and slogan ("you're fired!") were ready-made for the squared circle. What's fascinating, especially in retrospect, is how easy it was for the WWE to stage him as a babyface, the people's hero. In a clip from 1000 RAW Monday Night's Most Memorable Moments (WWE 2012) Trump marvels that the setup for WrestleMania was as cheap as dropping money from the grid on "Fan Appreciation Night" (29 January 2007). The clip shows McMahon blustering and posturing, riling the crowd. Trump interrupts, his image broadcast on a large screen, to issue a challenge that is capped by a rain of bills—we see a $\$ 50$ close-up—onto the fans: "Vince, you claim that you tell your audience what they want, what they like, and all of that nonsense. They want value. Who knows more about value than me, Vince." As McMahon sputters, the cameras swing between the fluttering bills and the grabbing fans. Trump's summary of that night is simple: "So the fans appreciated me, more than they appreciated Vince, because I gave 'em a lotta money" (WWE 2012). ${ }^{25}$ That the reasoning is shallow does not mean it's not true.

Even so, it would be a mistake to think the fans' allegiance was so simply bought. After all, only a small percentage of those present on the night nabbed a fifty. But for everyone in the room, along with those watching at home (whether live or later), what sticks is the image of Trump materializing in a tight close-up on the Jumbotron like a deus-ex-machina, or at least a god-in-the-television: a stand-up guy, disrupting McMahon's apparently vain attempts to claim pride of place as fan favorite. McMahon is working very hard to be hated, while all Trump has to do is turn up, throw a little shade Vince's way and promise more where that came from to win the contest for the fans' allegiance. It's a pattern we see repeated throughout the lead-up to WrestleMania XXIII, and in the event itself. It's the way Trump approached the campaign. It's how he's running the White House.

24. From the O'Jays, "For the Love of Money" (1973).

25 . The money—reportedly $\$ 25,000$ - was not Trump's; it was provided by the WWE (Waldron 2017). 
In the videos of his 2007 performances, McMahon comes out in a funky strut, thrusting his chest out, flinging his elbows and knees, and pulls the kinds of rubbery faces-smug and selfcongratulatory one minute, bug-eyed with perplexed rage the next- that play both to the crowd and to the camera much as the old stars did in vaudeville and early slapstick films. In contrast, Trump has no such calculation or physical grace in the ring or on the screen. Indeed, it is the failure to perform as the others do in the ring, as in the debates, that makes him appear more real, authentic. Travis Waldron, writing about the "Battle of the Billionaires" for the Huffington Post just after the inauguration, describes the difficulties Stone Cold Steve Austin (as the guest referee) and Vince McMahon had selling Trump's performance to the punters. "Trump, for all his usual braggadocio, wasn't helping," Waldron says:

From outside the ring, McMahon—a professional performer if there ever was one-was selling even the most minor details of the match. He was haranguing Austin, instructing Umaga [McMahon's surrogate in the ring] and engaging the crowd all at once. Trump was stiff. His repeated cries of "Kick his ass, Bobby!" [Bobby Lashley, Trump's surrogate] and "Come on, Bobby!" came across as stale and unconvincing. (2017)

Waldron is correct, I think, in his observation. Trump can be seen ringside, wandering aimlessly, making fists, and shouting with an ersatz enthusiasm, but unlike the other players, especially McMahon, he appears not to know where the cameras are, and seems unable to focus on the action in the ring; nor is he seen to be connecting with the spectators, even those who are within reach. The bad acting that is the hallmark of professional wrestling swirls around him. But he's not "acting." Or at least, he's not acting well. As a result, in some odd sense, he's the most "real" person in the 80,000 plus seat arena. ${ }^{26}$

For Waldron, it's fairly straightforward: "Wrestling is fake. Trump's punches weren't" (2017). This we can see when Trump clotheslines McMahon — that is, runs at him, arm outstretched to appear to catch his neck and knock him down. He actually connects with McMahon's neck (instead of his chest), potentially choking him. Trump knocks McMahon into the metal steps, potentially concussing him, and then punches him. ${ }^{27} \mathrm{We}$ can see it also in the stilted glee with which Trump participates in shaving McMahon's head. Close-ups show the wrestlers' hands barely touching McMahon, who is doing the work of selling his struggle to the punters in the live audiences and at home. The wrestlers cast looks at the cameras and to the spectators. McMahon wails and grimaces, pleads and looks heavenward, and somehow always makes eye contact with the home viewer. Trump has a good time, sort of; he even gets his hands a bit dirty, although he refuses to drink the beer Austin forces into his hands. But there's no evident effort to engage, even with the other men in the ring.

This dissociative performance seems the best he can do. In the "contract signing," an extended set piece where terms were set for the "Battle of the Billionaires," which was filmed for broadcast at an earlier Monday Night RAW (WWE 2013a), McMahon goes overboard to sell himself as a heel, riling up the crowd-"What a bunch of jerks!"-and building the heat that will

26. According to Waldron, the "Battle of the Billionaires was, at the time, WWE's highest-grossing pay-per-view broadcast, drawing 1.2 million pay-per-view buys and $\$ 24.3$ million in global revenue" (2017).

27. Waldron (2017) reports that in the practice session, with Ali, who was standing in for McMahon, Trump was given a lesson in how to punch without injuring his opponent, to show not to throw, but then as later with McMahon, Trump was hitting for real. 
peak in a few months' time: "This is a deal that is gonna make Donald Trump out to be the laughingstock of the world!" Trump enters, a "babe" on each arm; he's smirking like an overblown star waving to the little people, in way that was already cliché in the 1950s, and yet it seems to work for him. If the promoter - that is McMahon, of course-had wanted, Trump's entrance performed exactly the same way would have marked him as a classic heel, but because of the set-up, we see instead the emergence of a populist billionaire. The crowd goes wild, cheering and flashing their signs, chanting "Donald! Donald! Donald!" as McMahon doubles down on his contempt for Trump and the spectators: "You people, shut up!!"

For the big event, McMahon's surrogate is the Samoan Umaga, wild-eyed and puffing through clenched teeth; Trump's is the African American Bobby Lashley, whom McMahon calls, with intention to offend, "Sonny." The guest referee is WWE Superstar Stone Cold Steve Austin, a working-class hero, whose gimmick includes drinking a foaming can of beer in the ring. Austin makes a big show of putting Trump in his place here, but when it comes to WrestleMania, Trump and Austin are on the side, sharing the shaving, both somehow avatars of, and avengers for, the working class. The racial politics of this line-up-McMahon's alignment as a heel with a savage Pacific Islander, Trump's purchase of a virtuous and compliant black man's service, and Austin's stance as an aggrieved white man standing up for truth, justice, and the American way - are even more troubling than usual, a foreshadowing perhaps of Trump's fantastical assertions a decade later: he loves black people and they him; he is horrified by the "carnage" in cities like Chicago; he's certain there were some "very fine people" on both sides of the violence in Charlottesville, Virginia; and above all, he is outraged by black sports stars who should be fired for refusing his demand that they stand for the national anthem (Decode DC 2017; CNBC 2017; Al Jazeera English 2017).

The performance of contract signing carries the hallmarks of Trump's campaign and his current reign (WWE 2013a). It's done for show, of course, the real deal having been struck behind the scenes. There's even a discussion of "polls," with Trump talking up his numbers, as in: "Polls show 95 percent of Hollywood celebrities want your head shaved!" McMahon calls the fans "idiots" and Trump responds "To me, they look like a very smart group of people." Trump's face is frozen. It's beyond deadpan; his jaw seems clenched, especially when Austin talks to him directly. If it were me onstage, this would be a symptom of stage fright, but I think what we're seeing is Trump's default posture in the simultaneous lifting of the shoulders to appear taller, and then hunching over in a kind of incipient threat- "patriarchy unbuttoned," as Rebecca Solnit observes: "paunchy, in a baggy suit, with his hair oozing and his lips flapping and his face squinching into clownish expressions of mockery and rage and self-congratulation" (2017). The fans love him in spite of, or perhaps even because of, his refusal to react to an interlocutor, whether Stone Cold Steve Austin or Hillary Clinton. His almost aimless wandering, intruding into another performer's space one minute, shifting away toward a real or imagined audience the next in the ring looks much the same as his performance at the second debate with Clinton (NBC News 2016).

Even the handshake - made famous in the early months of his presidency-becomes an issue in the ring. He repeatedly rejects overtures from McMahon and Austin and then overplays his moments of physical contact. In spite of having talked through the scenario and rehearsed the moves, when push comes to shove he shoots the match-(intentionally or not) forgetting that it's 
what wrestlers call a "work" or a "job" —and does the deed for real. In the wrestlers' ring, as in the White House, he can't seem to get it right, nor does he appear to want to. He holds back, as if repulsed, freezes when Austin performs the stunner and then overcompensates both when he tosses McMahon over the table at the signing and when he punches him in the match itself. It's not really so different when he pulls off his address to the joint session of Congress (February 2017) only to resort to Twitter a few nights later, or pushes the Prime Minister of Montenegro aside to get to the front for a photo opportunity at the NATO summit (May 2017).

So how does this man, who is awkward at best in performance no matter what the arena, win and continue to sustain his hold over so many spectators, fans, and voters? It's too easy to talk about kayfabe - the con — and the susceptibility of his target audience - the marks, the suckers. For me, the key to understanding Trump's success is the affective mechanisms that produce the performance of which he plays a privileged part. That is, in the White House as in the squared circle, Trump doesn't have to do the job, to "act" in a knowing way. He can shoot the match, while everyone around him makes the show work in relation to the audience. It's what he expects. That's the way it worked for him during his long run in The Apprentice, after all, where "reality" was manufactured to his advantage according to the conventions of the genre: his words and actions remixed, processed and screened, framed and edited to suit the tropes of his role as a power-wielding businessman, the reception of his performance equally filtered and presented back to him. ${ }^{28}$ And that's how it worked in the "liveness" of the squared circle, as well.

During my time in Gleason's Gym, wrestlers often offered to show me the ropes more directly. It was a kind of hazing, I thought, and playful, a way of entertaining themselves and showing off. "Come on in," they'd beckon. "We'll make it easy for you." I never went beyond the "touch the muscles" level of engagement, but I vividly recall watching Rubio, a lucha librador, ${ }^{29}$ one afternoon as he "sparred" with a young boy. He repeatedly encouraged the boy to poke him, and in response, as a kind of reward, performed remarkable pratfalls-back flips and spinsnoisily exclaiming his pain, begging for mercy as he hit the mat. The boy barely moved, almost in awe of the effect, half-believing, or at least at the edge of believing, that somehow he was master of the moment.

So too Trump. It doesn't matter that he failed in executing the physical actions as rehearsed, that he was, in effect, shooting the match each time: shoving McMahon across the table at the "contract signing," going rigid while taking a Stunner from Stone Cold Steve Austin, clotheslining McMahon across the neck instead of the chest, and actually punching him during the event itself. In each instance, Trump's "opponent" was in fact an ally who put the action across to an audience that was primed to respond accordingly. This is how privilege works. He doesn't have to lift a finger, or rather he only has to lift a finger, and everyone jumps, whether it's to offer a smokescreen for a marginally licit action (firing the FBI Director, say) or to give him a Diet Coke along with his extra scoop of ice cream (Oppenheim 2017). It is also a symptom of

28. Trump's role as the "decider" was considerably overblown on Celebrity Apprentice, it seems. Much like wrestling, the producers were feeding lines and determining outcomes (see, for example, Schmidt 2017).

29. Lucha Libre is the Mexican version of professional wrestling (see Levi 2008). 
collusion: the way the men we see in conflict are actually on the same side performing on cue to a script dictated by a more powerful director behind the scenes. ${ }^{30}$

\section{From the Squared Circle to the Bully Pulpit}

What seems to perplex and infuriate Trump in the present moment is the failure of the performance in which he now stars to indulge his perambulations in the way it would in the squared circle-one in which he continues to hold a place alongside Hulk Hogan in the wrestling imaginary. Like Hogan, he stands for the fans. All he has to do is point at his latest enemy, call that enemy a name-Lyin' Ted, Crooked Hillary, Showboating Comey-and the fans will turn their vitriol in that direction, just as they went after Macho Man, a perennial fan favorite whose heel turn in the late 1980s took only a small dust-up over Miss Elizabeth, a swing or two at Hulk Hogan and a few choice obscenities lobbed at the spectators, to make him the most hated wrestler in the WWF line-up.

Look again at Trump's performance in the second debate with Hillary Clinton on 9 October 2016. He refuses a handshake, stands staring, wanders towards the audience and towards Clinton at various points, recites answers that are half-rote, and interjects brief insults"You're the puppet!" "Nasty woman!"-and odd gestures with the mic. She's smooth, rehearsed, showing us herself doing the job. He's doing what comes naturally to him, which turns out not to be much more than saying that he stands for the American people, who have been bullied and condescended to by the elites as embodied by Mrs. Clinton. All she ever had to do to seal her fate, really, was say the word "deplorables" or something like it; in retrospect it seems inevitable. We see her acting, as we see McMahon acting, not necessarily so broadly (pun not quite intended) to provoke but enough to show that she's not nearly so "real" as he is. She's also a woman, and like Miss Elizabeth, who caused the breakdown between Savage and Hogan by getting too close to the action, her entrée onto the platform is both transgressive by definition and inevitably tainted by the man to whom she is attached.

Watching the debate again, I recall how it felt sitting in the cheap seats at the top of Madison Square Garden for my first live experience of the WWF. New to the game, my husband and I leapt to our feet to cheer Mr. Perfect, only to be confronted by the spectacle of 19,998 fans vehemently booing. Somehow we'd missed the cues in the lead-up to the event: the obvious fact that any guy who claims to be perfect is doing so at the expense of "people like us." So too, Mrs. Clinton, with her poised smile, her polished answers, her very visible restraint when he makes a nonsense of an answer or blusters in her direction, misses the portion of her audience-large enough to make a difference - that reads such performances from an entirely other worldview.

The world of wrestling is visibly male-dominated in much the same way as the Trump White House and the GOP-driven Congress appear to be. True, it did take two women senators, Lisa Murkowski and Susan Collins, and one male senator, John McCain, to torpedo the Republican "lean repeal" of Obamacare. But overwhelmingly, the headlines went to McCain. Women who seek to do what men do are out of place in the wrestling world, irritants at best.

30. An equivalent effect is being exposed by the \#MeToo movement, which is underscored by a recognition that the abuse performed by men in power, whatever the industry, has been sustained by those around them. 
Women enter the squared circle, generally, as disruptive forces-hazards to be surmounted and sidelined. (Even the super-feminized Miss Elizabeth, in her day, as the source of conflict between Hulk Hogan and Randy Savage had to be shunted out of sight for the match to reach its celebrated climax.) Women who wrestle- "girl" or "lady" wrestlers-perform the same physical actions and bluster in much the same way, but the display of female bodies is sexualized, the response of male spectators often overtly obscene. Forget feminism. Femininity, femaleness itself, is perceived as an essential affront to the ethos of male honor. ${ }^{31}$ No wonder, then, that Trump, as he amps up his identification with "his" generals and talks trash with boy scouts and policemen, also continues to cavil against Clinton and other women (with frequent references to bodily fluids), as if their very presence threatens to contaminate the purity of the (male) body politic.

It does seem that what's happening on the political stage has come to resemble the World Wrestling Entertainment. Our ways of understanding the day-to-day are filtered through the scenarios of the oversaturated mediatized environments in which we live and work. Pro wrestling - as an affect factory, its players and fans together-makes great use of its almost instant feedback loops to keep just ahead of the sociopolitical curve, but the fundamentals stay the same: the babyface is the hero who stands with and for the people; the heel stands against. The face depends on us, our cheers, to lift him off the mat and give him the power to battle on; the heel wins in spite of, and to spite, us more often than not. The rules can be broken by the face, on our behalf, as a kind of rough justice. What we know to be right is affirmed, when we win, and even more so when we lose. Virtue, in fact, is most extremely visible in moments of loss, whether it's Hulk Hogan down for the count because the referee turned his back-or worse, turned heel—or the "fake media" picking on a president who remains resolute in pursuing today's pyrrhic victory while picking the pockets of his supporters. It is no more, really, than they expect in the face of the futility of the American Dream.

\section{Making a Play of Violence}

What is most distasteful about professional wrestling, I'm often told, is that in making a play of violence, it reifies the idea that two men cannot come within 18 feet of each other without wanting to throw a punch. At the heart of the game, as now seems to be true of our political system, is a belief that the world is a dangerous place. Violence is expressive in ways that words fail. The arc inscribed by a fist in full swing carries those who watch with it as it moves from the heart of the man to connect with the body of the opponent. This is how boxing, the "sweet science," is said to work "for real" while wrestling offers its excessive simulations for effect, for affect. Ironically, in order to construct such a heightened performance of violence, wrestlers must not only be in collusion; they have to be exceptionally careful of one another. That they withhold violence in order to show it was illustrated for me at Gleason's in the way the men would greet each other with a modified sort of "high 5": swiping two fingers as if to exaggerate the purpose of a handshake, its negation of violent intent. It means: "I could really hurt you, but I won't."

31. We hear this too in Trump's (and Chief of Staff John Kelly's) response to the current spate of resignations due to revelations of spousal abuse by White House aides: regret for the loss of "good men" whose "lives are being shattered and destroyed by a mere allegation" (Landler 2018). 
Contrast this to the outsized aggression of Trump's handshake, as he grabs the hand of yet another world leader, yanking and pumping in a show of power.

In the age of Trump, the show of violence in the ring and its potential, potent normalization in everyday life is certainly troubling. Since becoming president, Trump has not pulled back from inciting violent acts by his followers, any more than he has ceased to reduce his presentation of national and world events to a matter of winners and losers. When a congressional candidate bodyslams a reporter, as happened in Montana (May 2017), or a white nationalist knifes bystanders who were attempting to protect girls on a train in Portland, Oregon (May 2017), it's hard not to think that the world of wrestling has jumped the ropes and entered the real world. Such acts are starting to seem commonplace, mundane even-or at least they were until the Nazi flags, chants, violence, and murder in Charlottesville, Virginia (August 2017). Commentators seem less concerned for the breakdown of the rules governing a civil society, and more inclined to rationalize, to contest the meaning of such acts in terms of "deserving" or "undeserving" (like the poor); although at the moment they seem less inclined to equivocate while Trump carries on with his "both sides" response to what happened in Charlottesville, as if, as in wrestling, the question of who represents good and who evil is decided arbitrarily by a promoter pumping for punters-as such, a matter of entertainment rather than moral values. This is the violence that we see almost daily now.

But what of the ethos of wrestling, the way it trades on the idea that to be a "smart" (and not a "mark") is to know that the game is fixed and to carry on, even so, acting as if it is not? Is this not a symptom of what Zygmunt Bauman, in dialogue with Leonidas Donskis, has identified as "moral blindness" or "insensitivity"? Donskis says:

Evil is not confined to war or totalitarian ideologies. Today it more frequently reveals itself in failing to react to someone else's suffering, in refusing to understand others, in insensitivity and in eyes turned away from a silent ethical gaze. (2013:9)

Intrinsic to wrestling's performance of violence is the paradox of its theatricality. Antagonism is expressed, but the game is one of collusion rather than genuine opposition. Punches are thrown without causing injury. Pain is performed without being felt. In the arena, this passes for entertainment. Outside, we risk, in Donskis's words, becoming "somebody [who] loses their memory and their capacity to see and feel" (2013:10). He is describing the problem with Facebook, its redefinition of "friend," but I think the same holds true of the "smart" fan:

Here's a list of our new mental blocks. It includes our deliberate forgetting of the Other, our purposeful refusal to recognize and acknowledge a human being of another kind while casting aside someone who is alive, real, and doing and saying something right beside us. (2013:10-11)

How, then, can we "regain our perceptiveness in dark times" and "give back dignity as well as the idea of the essential unfathomability of human beings, not only to the world's greats but also to the crowd extras" (2013:11)?

Professional wrestling is seductive because it's self-explanatory. It tells us where we stand in ways that make instant sense. All we have to do is play along. It makes a vivid show of the violence that simmers under the surface, the easy lies of everyday life: the tensions of both domesticity and polity, more strife than bliss, especially when money is tight. Wrestling makes a 
spectacle of the power relations, deprivations, and precarities of the workplace. It deflects anxieties about the constant crumbling of the infrastructure and the decadent social order, its failed promises of community and communality. It re-mythologizes the threat of the unfamiliar and the foreign. (Look at the successful run WWE Superstar Jinder Mahal [Yuvraj Singh Dhesi] is having, flaunting his Indian-ness with Bollywood flare at exuberantly antagonistic fans.) Beneath the depths of the shallows, what is affirmed repeatedly in performance is the sure knowledge that the game is on and that it's a con, that there is little choice but to battle forward. This is the truth that professional wrestling reflects back to its fans, what Trump has been telling us in his own way almost every day of his campaign and presidency. How can the idealizations of a Hillary Clinton not appear corrupt in contrast, not simply an emblem of elitism but also, perhaps above all an encroachment of the feminine, endangering what's left of (white) masculinity?

Meanwhile, journalists-like wrestling commentators whose performances no longer seem so parodic - swing with the day's performance, scrambling as if they cannot possibly get ahead of the narrative curve. Listen to them announcing that Trump's address to the joint session of Congress in February 2017 or his order to bomb Syria in April 2017 demonstrates he's taken a turn toward the presidential, and then they're shocked—shocked! — when he goes back to Twitter, or when he talks of "shithole countries" in an Oval Office meeting (see Dawsey 2018), or is seen to be climbing into bed, metaphorically at least, with the repressive leaders of Russia, China, the Philippines, Turkey, and so on. And for our part, we follow avidly, debating both the president's performance and the commentary surrounding it, drilling into the micro details of each scenario and then swinging wide to demonstrate how smart we are at the macro levels at each stage as it plays out.

Everyone is selling to us, promoting their brands, claiming to be on our side, expressing astonishment that the corruption of our political system runs so deep, that the little guy is again getting shafted. The media surrounding Trump seems to stage its political stories at the intersection between sport and theatre much like wrestling, fitting the day's events into set scenarios, composing narrative arcs, inviting us to parse the performances for signs of the "real" or at least a break in the fake. Everyone seems now to get restless when the news slows. I find myself fighting back the impulse to do the New York Times reader's version of chanting "Borrrrrrrring" by hitting refresh or shifting to the Washington Post. There's no out out there. We want to be smart, but we also look to "mark out" as the fans say, to believe that what we are seeing is real conflict, real blood on the mat, real valor.

All of this is by way of saying that the White House and the press seem now to be working to wrestling's rules. While Trump himself hates bad press, like wrestling fans, he also can't stand it when things get too quiet. Neither can we. Trump signing an executive order, or firing the FBI Director (or Steve Bannon), or announcing that the USA is more interested in Pittsburgh than Paris, attacking his attorney general, and installing a brash, combative communications director who promptly trash-talks members of the White House staff and is fired, has become the equivalent of a wrestler like Mr. Kennedy grabbing the mic in Christchurch and issuing escalating insults: "Crusaders suck! ... The All Blacks suck! ... New Zealand is Australia's BITCH!” (Mazer 2017:200). Or Linda Dallas shouting “Brooklyn Sucks" at Gleason's (Mazer 1998:127). He may look to us like he's turning heel, but that doesn't mean 
the fans are turning against him for real. Not yet. Meanwhile, if Donald Trump is shooting the match in the White House, much as he did in the squared circle, then the obvious question is: who is the Vince McMahon, the money man who owns the game and directs the players for the entertainment of the punters. And who profits from the performance?

\section{"Fire and Fury"}

The pro-wrestling-ification of Donald Trump's presidency and the American body politic continued to escalate, even as I rushed to get this essay ready for its first release. On 10 August 2017, in an aside that was both off-script and off-topic, Trump issued a hyperbole-drenched threat against North Korea in response to a series of missile tests:

North Korea best not make any more threats to the United States. They will be met with fire and fury like the world has never seen. He has been very threatening, beyond a normal state. And as I said, they will be met with fire, fury and frankly power, the likes of which this world has never seen before. (in Baker and Sang-Hun 2017)

Trump's rhetorical flourishes seem to echo Hulk Hogan in his heyday. ${ }^{32}$ The key words— "fire and fury"-along with the emphasis on "the world has never seen" are repeated and with the addition of "frankly power" escalated into a climactic pronouncement. His posture also leans more toward the conventions of the squared circle than to a presidential press briefing. In the videos we see his arms folded across his chest, pulling up and away from the text in front of him and from his wife, Melania, who sits stoically to his left. He pauses between words, appears at moments to look at the text in front of him —or is he simply closing his eyes? —and then looks up again, punctuating the last words with a look to his right and then another to the center.

In a "Daily Cartoon" that was soon posted by The New Yorker, captioned "TRUMP SPEECHWRITERS BRAINSTORM” (Kenseth 2017), a Macho Man-like figure is sitting at a table, one hand on the championship belt, the other raised in an almost fist. Trump's words appear in the speech bubble: "They will be met with fire and fury like the world has never seen." He is joined by two other figures: a "Big Bad Baby" and a working man in overalls and hard hat, with a hammer. Big Bad Baby says "Oooh! Put a pin in that!" Since August, Trump has swung between conciliation and further provocation, perhaps most infamously with a tweet about the size of his "button":

North Korean Leader Kim Jong Un just stated that the "Nuclear Button is on his desk at all times." Will someone from his depleted and food starved regime please inform him that I too have a Nuclear Button, but it is a much bigger $\&$ more powerful one than his, and my Button works! (in Gambino 2018)

32. There is also similarity to Harry Truman's "the like of which has never been seen on earth"-enough for some commentators to imagine that Trump was attempting to reproduce pieces of an earlier discussion with advisors and speechwriters. The reference could also be biblical: "See, the Lord is coming with fire, / and his chariots are like a whirlwind; / he will bring down his anger with fury / and his rebuke with flames of fire" (Isaiah 66:15). There are enough sloganeers and evangelicals in Trump's circle to imagine such phrases being floated. It's just as likely, however, that Trump caught the words from a cartoon or a superhero movie. Even so, the inflection rings as close to "what the world is watching" (the WWF's old slogan) as anything else. 
At risk of stating the obvious, Donald Trump is no longer fighting Vince McMahon in the "Battle of the Billionaires." He's the President of the United States of America engaging in (what most of us hope is no more than) a rhetorical pissing contest with the Supreme Leader of the Democratic People's Republic of Korea. The matches (if his presidential appearances can be called that) he's now shooting are circumscribed by political convention, not kayfabe per se. When he lapses into the performance tropes of professional wrestling while enacting a presidential briefing, he generates heat, but the turmoil he creates is generic as well as political and, now it seems, existential.

What is it, exactly, that we are watching when we watch Donald Trump at a press conference going off-script to menace North Korea? As a performance of presidential power, it's somewhat askew — scary for most of us watching, but probably not so for Kim Jong-un, who is himself prone to posturing. It's not quite successful in professional wrestling terms either. Threat of nuclear holocaust aside, it's a dull drama. Trump seems to be straining toward an appearance of physical dominance at the same time that he fails to connect with the cameras and so misses the opportunity to achieve intimacy with the viewers. There is no in-the-know interlocutor, someone like "Mean" Gene Okerlund or Sean Mooney to construct our reception. His wife and his team are expressionless, and the voices of the reporters are muffled, mingled with the sounds of cameras snapping. In the aftermath, Trump's aides and cabinet members, along with the media, scurried to parse the fake from the fact, while Trump himself doubled down: "North Korea better get their act together, or they're going to be in trouble, like few nations have ever been in trouble in this world" (in Baker 2017). Standing in front of the flag, with his bleached hair and artificial tan, pressing his palms against the air in front of him for emphasis, his appearance recalled Hulk Hogan in the lead-up to "The Mega Powers Explode." We're worried, of course. Will he or won't he drop the bomb? But the big debate remains: how real is his performance and the disaster it portends? ${ }^{33}$

\section{Attempting Closure}

This article was first put into digital circulation via social media. Then in August 2017, we put it on the MIT Press/TDR website to make it available to readers more quickly than print publication allowed. Even now, I'm keeping an eye on the investigation by Special Counsel Robert Mueller and on the latest scandal. At times, Trump's performance seems to be spiraling beyond wrestling into a kind of demagogic camp: demanding a military parade down Pennsylvania Avenue, berating Democrats as treasonous for not applauding his State of the Union speech. His fighting words distract and deflect attention away from the real injuries being perpetrated: from the fiscal violence of "tax reform" to the physical violence of police, border, and immigration officers as they make America great again by ridding the country of those they say do not belong in America. This violence is gendered as well as racial, and it's becoming our "new normal" in the USA and well beyond. By the time you read this, there will have been other outrages. The details will change, but—barring a nuclear apocalypse — the outrageousness will stay much the same. If

33. See, for example: “Trump's Threat of War With North Korea May Sound Scarier Than It Is" (Fisher 2017); and "Trump Doubles Down on Threats Against North Korea as Nuclear Tensions Escalate" (Baker 2017). 
and when Trump exits the arena, the professional-wrestling-ification of political discourse will be complete.

When I began work on this article, over a year ago, I was oddly optimistic, inspired by the protests, as amused by Trump's obvious charlatanry as I am by professional wrestling's flamboyance, and, enraged as I was, I was also thrilled to imagine myself standing on the side of truth and justice. It was empowering to be writing about the alignment between the hyperrealism of the ring and the surrealism of the Trump White House. I felt smart. I used to see Hulk Hogan and Macho Man Randy Savage circling each other from one big match to another, their preposterous performances highlighted by the WWE's in-house pundits, delighting and infuriating the punters in ways that were satisfying even though, or perhaps because, the drama stayed in the frame of the game, predictable to all but the most naive mark. So too Trump, I thought. Even though he seems to be shooting, he's contained by the game, and the gamedemocracy—will keep us safe. Now I am not so sure.

\section{References}

Al Jazeera English. 2017. “Trump: Fire players who kneel during US national anthem.” YouTube, 23 September. Accessed 18 February 2018. https://www.youtube.com/watch?v=LFFMpb9hw_Y.

Barthes, Roland. 1972. “The World of Wrestling.” In Mythologies. Translated by Annette Lavers, 15-25. NY: Hill \& Wang.

Bauman, Zygmunt, and Leonidas Donskis. 2013. Moral Blindness: The Loss of Sensitivity in Liquid Modernity. Cambridge, UK: Polity Books.

Baker, Peter. 2017. “Trump Doubles Down on Threats Against North Korea as Nuclear Tensions Escalate." New York Times, 10 August. Accessed 11 August 2017. www.nytimes.com/2017/08/10/world/asia/north-korea-trump.html.

Baker, Peter, and Choe Sang-Hun. 2017. "Trump Threatens 'Fire and Fury' against North Korea if It Endangers U.S.” New York Times, 8 August. Accessed 9 August 2017. http://www.nytimes.com/2017/08/08/world/asia/north-korea-un-sanctions-nuclearmissile-united-nations.html.

Berlant, Lauren. 2011. Cruel Optimism. Durham, NC: Duke University Press.

CNBC. 2017. "President Donald Trump on Charlottesville | CNBC." YouTube, 15 August. Accessed 18 February 2018. www.youtube.com/watch?v=JmaZR8E12bs.

Dawsey, Josh. 2018. “Trump derides protections for immigrants from 'shithole' countries.” Washington Post, 12 January. Accessed 18 February 2018. www.washingtonpost.com/politics/trump-attacks-protections-for-immigrants-fromshithole-countries-in-oval-office-meeting/2018/01/11/bfc0725c-f711-11e7-91af31ac729add94_story.html?utm_term =.8e82e5eb413b.

Decode DC. 2017. "Donald Trump proclaims American carnage must end | Donald Trump inauguration.” YouTube, 20 January. Accessed 18 February 2018. www.youtube.com/watch?v=xtrcGQdacgY. 
Faludi, Susan. 1999. Stiffed: The Betrayal of the Modern Man. London: Chatto \& Windus.

Fisher, Max. 2017. “Trump’s Threat of War With North Korea May Sound Scarier Than It Is.” New York Times, 9 August. Accessed 10 August 2017. www.nytimes.com/2017/08/09/world/asia/trump-north-korea-nuclear-war.html.

Gambino, Lauren. 2018. "Donald Trump boasts that his nuclear button is bigger than Kim Jong-Un's." The Guardian, 3 January. Accessed 6 February 2018. http://www.theguardian.com/us-news/2018/jan/03/donald-trump-boasts-nuclearbutton-bigger-kim-jong-un.

GB. 2016. "Donald Trump acting presidential, Waterbury, CT 423 16.” YouTube, 24 April 2016. Accessed 6 February 2018. www.youtube.com/watch?v=1NEBuSk7X1A.

Goffman, Erving. (1952) 1997. "On Cooling the Mark Out: Some Aspect of Adaptation to Failure." In The Goffman Reader, edited with introductory essays by Charles Lemert and Ann Branaman, 3-20. Malden, MA: Blackwell Publishers.

Grant, Tim. 2017. "Skip the Opera. Go See Some Pro Wrestling." New York Times, 11 July. Accessed 11 July 2017. www.nytimes.com/2017/07/11/opinion/babyface-cauliflowerbrown-wrestling.html.

Grynbaum, Michael M. 2017. “Trump Tweets a Video of Him Wrestling 'CNN' to the Ground." New York Times, 2 July. Accessed 6 February 2018. www.nytimes.com/2017/07/02/business/media/trump-wrestling-video-cnn-twitter.html.

Heath, Chris. 1998-1999. “Stone Cold Steve Austin.” Rolling Stone 802-803 (24 December-7 January):122-30.

Hochschild, Arlie Russell. 2016. Strangers in Their Own Land: Anger and Mourning on the American Right. New York: The New Press.

Isenberg, Nancy. 2016. White Trash: The Untold History of Class in America. New York: Penguin.

Iyengar, Shanto, Gaurav Sood, and Yphtach Lelke. 2012. "Affect, not Ideology: A Social Identity Perspective on Polarization.” Public Opinion Ouarterly 76, 3 (Fall):405-31.

Jenkins, Henry. 1992. Textual Poachers: Television Fans and Participatory Culture. London: Routledge.

Jenkins, Henry. 2005. “Never Trust a Snake': WWF Wrestling as Masculine Melodrama.” In Steel Chair to the Head: The Pleasure and Pain of Professional Wrestling, edited by Nicholas Sammond, 33-66. Durham, NC: Duke University Press.

Kenseth, Lars. 2017. “Trump speechwriters brainstorm.” Daily Cartoon, The New Yorker, 9 August. Accessed 10 August 2017. www.newyorker.com/cartoons/dailycartoon/wednesday-august-9th-trump-speechwriters-brainstorm.

Kimmel, Michael. 2013. Angry White Men: American Masculinity at the End of an Era. New York: Nation Books.

Kimmel, Michael. 2016. "Preface." Angry White Men: American Masculinity at the End of an Era. Unpublished manuscript for forthcoming new edition. 
KrisAnderson97. 2016. "WWE WrestleMania 5 - Ringside with Sean Mooney \& Donald Trump" [1989]. Daily Motion, 21 February. Accessed 17 April 2017. $\mathrm{http} / / /$ www.dailymotion.com/video/x3tf25t.

Landler, Mark. 2018. “Trump Appears to Doubt \#MeToo Movement, Saying 'Mere Allegation' Ruin Lives.” New York Times, 10 February. Accessed 11 February 2018. www.nytimes.com/2018/02/10/us/politics/trump-porter-me-too-movement.html.

Levi, Heather. 2008. The World of Lucha Libre: Secrets, Revelations, and Mexican National Identity. Durham, NC: Duke University Press.

Martin, Jonathan, and Jeremy W. Peters. 2016. "Donald Trump to Reshape Image, New Campaign Chief Tells G.O.P.” New York Times, 21 April. Accessed 6 February 2018. www.nytimes.com/2016/04/22/us/politics/donald-trump-to-reshape-image-newcampaign-chief-tells-gop.html.

Mazer, Sharon. 1990. “The Doggie Doggie World of Professional Wrestling.” TDR 34, 4 (T128):96-122.

Mazer, Sharon. 1998. Professional Wrestling: Sport and Spectacle. Jackson: University Press of Mississippi.

Mazer, Sharon. 2017. “The Game of Life.” In Performance and Professional Wrestling, edited by Broderick Chow, Eero Laine, and Claire Warden, 196-206. London: Routledge.

Miller, Toby. 2001. Review of Professional Wrestling: Sport and Spectacle. TDR 45, 2 (T170):17475.

NBC News. 2016. "The Second Presidential Debate: Hillary Clinton and Donald Trump (Full Debate)." YouTube, 9 October. Accessed 15 May 2017. https://www.youtube.com/watch?v=FRII2SQ0Ueg.

Oppenheim, Maya. 2017. "Donald Trump gets two scoops of ice cream while everyone else gets one." The Independent, 12 May. Accessed 19 August 2017. www.independent.co.uk/news/world/americas/donald-trump-two-icecream-scoopsguests-get-one-time-magazine-diet-coke-thousand-island-dressing-a7732101.html.

Remnick, David. 2017. "One Hundred Days.” The New Yorker, 1 May:17-21.

Ridout, Nicholas, and Rebecca Schneider. 2012. "Precarity and Performance: An Introduction." TDR 56, 4 (T216). Accessed 18 April 2017. https://www.mitpressjournals.org/toc/dram/56/4.

Rogers, Nick. 2017. "How Wrestling Explains Alex Jones and Donald Trump." New York Times, 25 April. Accessed 25 April 2017. www.nytimes.com/2017/04/25/opinion/wrestlingexplains-alex-jones-and-donald-trump.html.

Schmidt, Samantha. 2017. "Clay Aiken says Trump didn't make the decisions to fire people on 'Celebrity Apprentice.” Washington Post, 12 July. Accessed 12 July 2017. www.washingtonpost.com/news/morning-mix/wp/2017/07/12/clay-aiken-says-trumpdidnt-make-the-decisions-to-fire-people-on-celebrity-apprentice.

Smith, R. Tyson. 2014. Fighting for Recognition: Identity, Masculinity, and the Act of Violence in Professional Wrestling. Durham, NC: Duke University Press. 
Smith, R. Tyson. 2017. "Will Trump Continue to Pull from a Pro Wrestling Playbook?” Huffington Post, 30 March. Accessed 30 March 2017. www.huffingtonpost.com/entry/will-trump-continue-to-pull-from-a-pro-wrestlingplaybook_us_58dd20e3e4b04ba4a5e25152.

Solnit, Rebecca. 2017. "From Leering to Lying." London Review of Books 39, 2 (19 January). Accessed 20 January 2017. www.lrb.co.uk/v39/n02/rebecca-solnit/from-lying-to-leering.

TheOneWWEGuy. 2010. “WWF Wrestlemania 5 - Hulk Hogan Interview” [1989]. YouTube, 1 December 2010. Accessed 17 April 2017. www.youtube.com/watch?v=Oyx9z1qUPS4.

Trump, Donald J. 2004. Think Like a Billionaire: Everything You Need to Know About Success, Real Estate, and Life. New York: Ballantine Books.

Waldron, Travis. 2017. "The Definitive History of That Time Donald Trump Took a Stone Cold Stunner." Huffington Post, 14 February. Accessed 15 February 2017. www.huffingtonpost.com/entry/donald-trump-wwewrestling_us_58a35601e4b094a129ef8c46.

Willamette Leadership Academy. n.d. “About Us.” Accessed 5 May 2017. www.willametteleadershipacademy.net/about-us.html.

WWE. 2012. "Donald Trump Gives Away Money on Fan Appreciation Night." 2012. 1000 RAW Monday Night's Most Memorable Moments. YouTube, 3 July 2012. Accessed 8 May 2017. http://www.youtube.com/watch?v=ybtwzNpJ0YA.

WWE. 2013a. "Mr. McMahon and Donald Trump's Battle of the Billionaires Contract Signing" [2007]. YouTube, 8 December 2013. Accessed 8 May 2017. www.youtube.com/watch? $v=v V e V c V B W \_C E$.

WWE. 2013b. "Bobby Lashley vs. Umaga - Battle of the Billionaires Match: WrestleMania 23" (1 April 2007). YouTube, 25 February 2013. Accessed 8 May 2017. https://www.youtube.com/watch?v=M0-ChqIib_w.

Sharon Mazer is Associate Professor of Theatre and Performance Studies at Auckland University of Technology. Best known for her work on popular performance-in particular, for her book Professional Wrestling: Sport and Spectacle (University Press of Mississippi, 1998)-she currently focuses her research on diverse aspects of theatre and performance in Aotearoa New Zealand.smazer@aut.ac.nz 


\section{Working Loose}

\section{A Response to "Donald Trump Shoots the Match" by Sharon Mazer}

\section{Claire Warden, Broderick Chow, and Eero Laine}

[Ed. note: On 14 November 2017, TDR received this response to Sharon Mazer's article posted on 24 August 2017. Mazer has since updated her article. We do not believe these updates affect this response. We've added corresponding page numbers from the current version of the Mazer to the citations of quotes from the original.]

In her TDR article, "Donald Trump Shoots the Match," Sharon Mazer examines the current state of US presidential politics by drawing connections between Donald Trump and professional wrestling. As she notes, Donald Trump has a relationship with professional wrestling and WWE that goes back to the 1980s. The hyperbole, the spectacle, the violence, the history of troubling representations and storylines, and the often intentional muddying of truth and fiction are all key facets of professional wrestling; Mazer notes each in turn, even reading the recent nuclear tensions between the US and North Korea through the 1989 Hulk Hogan vs. "Macho Man” Randy Savage storyline, "The Mega Powers Explode." This leads Mazer to make a number of pithy and pertinent remarks, including the no-doubt-accurate postulation that "the 2016 election might best be viewed as a kind of grudge match [between prominent personalities], part of a long-running cycle in which the heat generated by the campaign, played to enrage, trumped any more rational debate" (2017b:10 [2018:184-85]). No one who witnessed the epoch-defining events of Winter 2016/17 could question Mazer's conclusion here.

Mazer also reads Trump's campaign and presidency through events such as the Wrestlemania XXIII "Battle of the Billionaires," where Donald Trump participated in a match with his storyline rival and WWE owner, Vince McMahon. Since Trump first entered the presidential race in June 2015, such readings have littered the editorial and opinion sections of newspapers large and small, including Oliver Lee Bateman's December 2016 "Wrestling, Politics, and the Violent Realities of 2016" to which the current three authors contributed. Jeremy Gordon's New York Times article, for instance, "Is Everything Wrestling?" asserts that Trump's election represents a sea change in US, and indeed, global culture. "With each passing year," he writes, "more and more facets of popular culture become something like wrestling: a stage-managed 'reality' in which scripted stories bleed freely into real events, with the blurry line between truth and untruth seeming to heighten, not lessen, the audience's addiction to the melodrama" (2016). While not necessarily wrong, Gordon's article is indicative of news commentary from the past year that reasserts the unhidden connection between Trump and professional wrestling - the association between the two is little secret, even as many articles on the topic present it as somehow revelatory. Trump is, after all, and as the WWE website points out, the first "WWE Hall of Famer [to] ever hold the distinguished title of U.S. Commanderin-Chief" (WWE 2017). In the view of such evidence, wrestling is certainly and strikingly representative of the current post-truth era, but it is also representative of politics more broadly and Trump is certainly not the first wrestler to intervene in politics (or vice versa). Wrestling, these pieces argue, is so obviously fake, so staged, so phony, that it perfectly represents the 
condition of modern politics-we contend this is true in some ways regardless of who won the election. However, what many writers seem to miss (Bateman excepted) is the understanding that professional wrestling is a performance form in which players and spectators together "keep kayfabe," which is to say, they maintain the pretense that the staged event is real and, importantly, also thus understand that it can be radically changed.

Unfortunately, and surprisingly, Mazer-who in 1998 published the seminal Professional Wrestling: Sport and Spectacle—seems to make a similar mistake in "Donald Trump Shoots the Match.” Her analysis of wrestling and politics concludes that fans/voters were "duped" by Trump, that he has "converted his fans into voters" (2017b:1 [2018:175]). While it is problematic that Mazer does not provide verifiable evidence for her claim (and indeed, some evidence we present below demonstrates that such assertions are untrue), a larger problem is her claim to ownership over academic studies of professional wrestling, and the way that her critical position precludes any knowledge beyond a traditionally academic knowledge (and, it seems, any knowledge beyond her own). ${ }^{1}$ Mazer does not seem to allow for the average fan to experience anything resembling critical thought or introspection and forecloses any hope for the performance form itself. In contrast to Mazer's flat condemnation of professional wrestling's complicated mix of theatricality and performance, deceit and truth, in this response, we suggest that professional wrestling is a means for fans and wrestlers alike to think critically about contemporary politics and the state of the world. As a performance form that spans the past century and has significant traditions outside the US, such alternative ways of knowing, we argue, emerge performatively through the form of professional wrestling itself.

This essay posits three provocative ideas: (a) that if we watched politics more like wrestling fans then we wouldn't have a Trump presidency; (b) if we approached work as wrestlers do (as collaborators rather than as antagonists) then we would have a stronger opposition in a political sense; and (c) if we celebrated the rise of women's wrestling (and, to an extent, the broader diversification of professional wrestling) we could challenge the misogyny and bigotry that are all too prevalent in political discourse and everyday life. We intend to confront some of the claims of Mazer's article, collegially but directly, enabling readers to access multiple arguments outside the singular narrative that Mazer presents. We suggest that professional wrestling might actually provide hope, that it might be the solution rather than the problem. To use Mazer's terminology, instead of despairing over the "pro-wrestling-ification of Donald Trump's presidency and the American body politic" (2017b:20 [2018:195]), we suggest how professional wrestling and its conventions of spectatorship provide a means of challenging current political discourse.

1. Throughout the article, Mazer takes on the wrestling role of the established heel, looking down on any newcomers. She mentions R. Tyson Smith as someone who has done his "homework." Smith has a PhD in sociology, spent a number of years doing ethnographic research, and published a well-received book on the topic from Duke University Press. She also presents Nick Rogers (a PhD candidate) as someone who has somehow "helicoptered in" and "picked up a bit of the lingo." And while we may not entirely disagree with Mazer's characterization of the academy as a process of "jobbing up the food chain," we believe Smith made the point better in 2014 (Smith 2014b). 


\section{Wrestling Spectatorship and Antitheatricality}

To understand wrestling, you have to be a fan.

Wrestling spectatorship is a more expansive and complex experience than Mazer suggests. Her reading of wrestling presents the fan as a passive force in the wrestling event, coerced into certain affects and even ideas by the wrestlers and promoters. The history and attributes of professional wrestling prompt this reading, as a result of wrestling's unabashed low-brow aesthetic with roots tracing back to the 19th-century carnival, a genealogy that readily lends itself to wrestling's paradoxical theatricality. As we have argued in the introduction to Performance and Professional Wrestling, "wrestling represents a special case in that it is ance scripted, theatrical, and fake, and improvised, performed, and real" (Chow, Laine, and Warden 2017:3). In wrestling, objects and actors continuously shift between enacted roles and phenomenologically present, "real" bodies and things. This means that "the professional wrestling audience is an active audience. Wrestling audiences are particularly adept at not only parsing the theatrical aspects from performance, but perhaps more interestingly, are very capable of holding them in mind at the same time" (Chow, Laine, and Warden 2017:4).

Despite what we argue in the book for which she herself provides the elegiac epilogue, Mazer underestimates the role of the audience in the spectacle. Matches where spectators are invited to take part through developed and improvised plot and character twists and turns (see Warden 2017; Di Benedetto 2017; Ezell 2017; and Mazer 1990) are treated by Mazer in her recent article as "tricks" that are put over on the audience. For instance, Mazer's seemingly perceptive analysis of "cooling the [fans] out" to achieve an even bigger pop of excitement (2017b:5 [2018:179]) only works when we assume that spectators are not themselves aware of such devices - a concern that stretches forward a long history of antitheatricality.

Thus, the problem with Mazer's criticism of professional wrestling is that the same criticism works for much of theatre and performance. Take Chris Hedges, who similarly complains that

The bouts are stylized rituals. They are public expressions of pain and fervent longing for revenge. The lurid and detailed sagas behind each bout, rather than the wrestling matches themselves, are what drive crowds to a frenzy. These ritualized battles give those packed in the arena a temporary, heady release from mundane lives. The burden of real problems is transformed into fodder for high-energy pantomime. (2009:5)

Of course, it is debatable whether a "heady release" might parallel the supposedly austere catharsis of tragedy or the satisfaction of performance art; however, Hedges's and Mazer's bothered descriptions of professional wrestling are easily ported from the arena to almost any other performance form that seeks and holds an audience. While in traditional theatre, events are more likely to occur in a drawing room than in a ring, we can certainly observe the ritual of exposition and rising action leading to a climax and then also gasp as lurid details of the past are revealed through dialogue and crafty twists of plot, or watch our "real problems" become the basis for theatrical fantasy. Mazer, like Trump, is shooting the match-she's giving up the business (of theatre and performance studies) and embracing those longstanding (platonic) critiques of theatre and performance. 
These antitheatrical arguments thus reproduce some frequent straw man critiques of fans and fandom. Citing Nicholas Ridout and Rebecca Schneider's 2012 special issue of TDR on precarity, Mazer puts professional wrestling forward as "a kind of 'affect factory," noting that "[f]andom is contagious" (2017b:4 [2018:178]). "In their often feverish debates about what's happening and how it's being constructed for their consumption," she writes, "fans solidify their attachments to the game and amplify the promoter's pitches for audiences" (4 [178]). ${ }^{2}$ Indeed, the idea of professional wrestling as an affect factory is perhaps a useful analytic to take up, but for reasons that Mazer neglects in her outright dismissal of the form. In many ways professional wrestling might be framed as an affect factory or perhaps more poignantly as an outgrowth of what Ridout and Schneider call "the neoliberal affect factory" (2012:9). We would want to echo their questions (rather than, say, closing arguments on such a diverse form of performance entirely) when they write:

While Marx critiqued alienated labor as a negative aspect of capitalism's use and abuse of labor for the gains of the capitalist, Brecht attempted to deploy alienation positively in order to provoke critical thought that might lead to actions of resistance and change. Might a similar technique regarding precarity be emerging in performance-based art, in which a body producing affective engagement simultaneously critiques deployments of affective engagement in the neoliberal affect factory? (2012:9)

Similarly, we ask, might a performance form that is apparently so embedded in retrograde politics "provoke critical thought that might lead to actions of resistance and change"? Indeed, perhaps what Brecht saw in sports, we might see in professional wrestling. The young Brecht writes in his 1926 essay "Emphasis on Sport": "Make no bones about it, we have our eye on those huge concrete pans, filled with 15,000 men and women of every variety of class and physiognomy, the fairest and shrewdest audience in the world" ([1926] 1964:6). The wrestling form calls attention to itself as it outperforms its own realism and almost intentionally makes itself ridiculous, demanding critical attention and shrewdness.

In addition, Mazer mischaracterizes Henry Jenkins's work as he describes the popular idea of what a fan is and what a fan does. In his breakthrough text from 1992, Jenkins does describe the prevailing stereotypes of fans that Mazer offers up only to spend the rest of the book writing with "the assumption that speaking as a fan is a defensible position within the debates surrounding mass culture" (1992:23). Throughout Textual Poachers (and, indeed, his career) Jenkins points to how such negative and dismissive ideas of fandom overlook important understandings and new models of knowledge that might grow out of fandom through the immense investment that fans have in their objects of interest. Despite this, Jenkins is not immune to sweeping assumptions about wrestling's ideological foundations and Mazer cites him whole cloth to make a connection between wrestling and fascism. ${ }^{3}$ However, as Sam Ford

2. In a footnote, Mazer acknowledges that with new technologies "the circulation of fan culture escalated both in pitch and range" (2017b:4 [2018:178]). Of course, Mazer is certainly not the first to acknowledge, let alone study, the importance of technologies and new media on the circulation of popular culture and the ways that such work intervenes on professional wrestling (see Hadley 2017; Laine 2017; Ware 2017; Wrenn 2007; and many others).

3. It is worth noting that professional wrestling is incredibly malleable in its ability to encompass various ideologies and practices from morality plays (Morton and O’Brien 1985) to contemporary ritual (Ball 1990) to the US War 
reminds us in a recent and essential text on wrestling fandom and masculinity: "it's important to understand wrestling fandom as a consistent site of debate about the direction of pro wrestling stories, negotiation about what makes for a good character or storyline direction, and collective resistance against the creative direction planned by promoters" $(2018: 179){ }^{4}$

A final problem with this antitheatrical, antifan reading of professional wrestling, is that it is factually wrong. Mazer's research on fans does not cite any discourse by actual fans. Had she, for instance, glanced at the "Donald Trump in WWE" megathread on Reddit's / $\mathrm{r} /$ squaredcircle (one of the most important online wrestling fan communities), her argument may have been very different. In contrast to Mazer's statement that "these [wrestling fans] are the people who voted for Trump" (1), the /r/squaredcircle thread exhibits a diversity of opinion, leaning somewhat more anti-Trump, while surprisingly lacking the vitriol we see in other online forums or social media political discussions. ${ }^{5}$ Most importantly, the Reddit thread demonstrates that these fans are hardly innocent dupes, but instead are thinking about politics through wrestling concepts. Take this exchange between [deleted] and Agent21EMH:

[deleted]: We worked ourselves into a shoot.

Agent21EMH: I think Donald shot himself into a work seriously. ${ }^{6}$

Behind the playful, clever joking with wrestling's argotic phrases ("work" and "shoot") is a serious discussion of the nature of belief, representation, and affective investment in populist politics not entirely dissimilar to the concerns Mazer herself rehearses in her article. Our point, therefore, is that Mazer's characterization of wrestling and its spectators is not only inaccurate, but also that wrestling's conventions of spectatorship might position wrestling fans to understand contemporary politics and discourse. Even if every single wrestling fan is seduced by the spectacle of the match, overwhelmed by the fervent emotions of watching their heroes overcome impossible odds, the potential for critique is built into the wrestling event. Especially today, the wrestling event requires the distance of critique, the ability to see the wrestling matches for what they are-theatrical performance. The fan thus takes up a near constant critique of the match, parsing the shoot from the work, looking for cracks in the corporate façade. What if, in fact, the ways of encountering professional wrestling - that is, the ways that professional wrestling spectators engage the sport-are useful critical tools for engaging with not just Trump, but politics more broadly?

Part of such a project would entail acknowledging the possibility for theoretical tools that emerge from the form itself. In The Queer Art of Failure, Jack Halberstam articulates the concept

on Terror (Nevitt 2010) to S/M practice (Rahilly 2005). See also Nicholas Sammond's introduction to Steel Chair to the Head (2005) where he offers a "Brief and Unnecessary Defense of Professional Wrestling" by reading various professional wrestling events through a variety of critical techniques from psychoanalysis, material historicism, and other popular performance forms such as punk music.

4. Ford's article is particularly important in this sense as it reviews the diverse literature on resistant fandom and the gendered performances of professional wrestling.

5. This would seem to echo the picture of wrestling fans Mazer encounters during her fieldwork, which is recounted in her most recent $T D R$ article, which she describes as "a diverse mob: young people and families, older men and women, black and white, Asian and Hispanic, gay and straight, professional and blue collar, dressed down and dressed up" (2017b:5 [2018:179]). Mazer's earlier experiences contradict her conflation of Trump voters and wrestling fans.

6. On Reddit, comments by users who no longer have accounts on the site show as [deleted]. 
of "low theory." "As long as there is an entity called high theory," he writes, "even in casual use or as shorthand for a particular tradition of critical thinking, there is an implied field of low theory" (2011:16). Halberstam's concept is applicable to the nonacademic, but expert knowledges of wrestling fans and wrestlers alike, who enthusiastically embrace what professional wrestling has to offer as a form of low theory. Professional wrestling pushes the boundaries of the binary opposition between high and low that Halberstam questions ("why should we invest in something that seems to confirm rather than upset the binary formation that situates it as the other to a high theory?") (15). In the context of professional wrestling, low theory does not simply reaffirm the binary, but aggressively enacts a lowness that assaults and offends many upper-class and academic assumptions. One of the lowest, low-brow narrative performance forms, professional wrestling is a sportive entertainment whose participants and fans often reject academic (or outsider) theorization. At the same time, pro wrestling itself performs a form of critique and theory that offers important insights through its practice and performance.

\section{Wrestling, Collaboration, and Embodied Knowledge}

To understand wrestling, you have to get in the ring.

The most insightful discussion in "Trump Shoots the Match" is Mazer's astute analysis of Trump's failure to "work." Closely reading Trump's appearance on 2013's "Battle of the Billionaires," Mazer rightly suggests that "in the White House as in the squared circle, Trump doesn't have to do the job, to 'act' in a knowing way. He can shoot the match, while everyone around him makes the show work in relation to the audience" (2017b:16 [2018:190]). In the context of a presidency whose first 10 months have been defined by Trump's failure to do the job and respond effectively to any of the many crises of 2017, Mazer's argument is crucial, pointing to the possibility of what happens when the "collusion" (18) of the "affect factory" begins to break down. Indeed, Mazer provides one of the clearest explanations of the concept of "privilege" in this analysis: privilege is the ability to win a game without knowing any of its rules.

However, Mazer's analysis of the "work" of wrestling, a shorthand term for the performative labor of representing a fiction, fundamentally misunderstands the form from an embodied perspective. As she admits, in her 1998 study of Gleason's Gym she "never went beyond the 'touch the muscles' level of engagement," seeing the wrestlers' offers to show her the moves and tricks of the game as "a kind of hazing" (1998:16). But perhaps behind the wrestlers' braggadocio was a more fundamental, methodological point: it is impossible to fully understand wrestling unless you understand it as an embodied practice.

Mazer has been criticized for this oversight before, most strongly by sociologist Laurence de Garis. In his article "Experiments in Pro Wrestling: Toward a Performative and Sensuous Sport Ethnography," de Garis—who was one of Mazer's informants in Professional Wrestling: Sport and Spectacle - argues that while he does not wish to "impugn Mazer's empirical findings nor her theoretical interpretations" (de Garis 1999:66), her "transcendental" subject position of "dynamic invisibility" (67) compromises her research into pro wrestling. In crude terms, at several points in her ethnography, Mazer was quite the opposite of a privileged ethnographic researcher, but instead, a mark. "What is missing here," he writes, is the element of play so 
common in human transactions" (de Garis 1999:69). By refusing to "play along" in order to maintain her objectivity, Mazer draws false conclusions about the form:

In the literal sense, Mazer's refusal to get in the ring limits the knowledge to which she has access. That is, by not entering the ring, by distancing herself as a "scholar" and "female," Mazer missed out on some valuable insights into the performance and meaning of pro wrestling-insights that could have been gained through a performative approach to ethnography but not through a strict reliance on visual data. (1999:71)

What she therefore does not have access to is the nature of wrestling as an embodied skill or technique, which, we suggest, contributes to her almost entirely negative reading of the form and its politics.

It is quite obvious that because wrestling is not a real fight, wrestlers are actually cooperating. However, because of Mazer's refusal to enter the ring, she does not register the value and meaning that wrestling work might hold for both worker and spectator. This is signaled by her repeated use of the word "collusion," an immediately negative framing that suggests fraudulence and malice behind the work (one would never speak of actors "colluding" to put on a play, for example). What Mazer sees in such collusion is a kind of normalization of violence and "moral blindness" (2017b:19 [2018:193]). The smart mark who knows the violence isn't "real," the game is fixed, and yet carries on as if everything is real, Mazer suggests, is symptomatic of a contemporary culture of cynicism. We have lost sight of the Other as well as our will or desire to distinguish fake violence from real.

We argue that though it is true that wrestling audiences are entertained by the spectacle of violence, at the same time they take pleasure and meaning from a much more fundamental theatrical spectacle: the collaborative labor of the "show." Furthermore, we suggest this form of collaborative labor might model a powerful and valuable embodied form of politics that is ever more important in the face of a Trump administration.

In his 2014 article for TDR, “Work' and 'Shoot': Professional Wrestling and Embodied Politics," Broderick Chow documents his time in a London wrestling school, learning the techniques of wrestling with a highly diverse group of people. What is striking is the degree of care, trust, and friendship expressed in the physical practice of wrestling: the "lock-up" or "tieup," an almost mythic embodiment of physical conflict, serves instead as a way of establishing a communication between bodies. Suplexes and body-slams are taught with the same care as adagio acrobalance, and while strikes "hurt," temporarily, they necessarily require the trust of the partner. As Chow argues, the physical practice of wrestling work, seen in relation to wrestling's particularly exploitative labor economy models a politics of friendship (2014:80-85).

Other analyses of wrestling have also touched on the value that the embodied practice of friendship might hold for wrestlers, particularly at a grassroots level (see Smith 2014a). Betty Gilpin, who plays Debbie Eagan/Liberty Belle on the Netflix series GLOW, echoes this view in an insightful essay for Glamour magazine. Describing an early training session with experienced wrestler Kia Stevens, she notes the degree of care in Stevens's touch: "Kia's arms wrapped gently around my neck like my head was an injured piglet" (Gilpin 2017). She notes the changes she felt as she grew increasingly comfortable with the practice: "For the first time in my life, I could feel my whole body listening. Go here. Come here. Be still. Take charge. [...] My body was 
listening, talking. To her body, to her body, to her body" (2017). Gilpin's experience, like Chow's, suggests wrestling work promotes an ethical, embodied responsiveness, in contrast to the "insensitivity" Mazer emphasizes, drawing on Zygmunt Bauman and Leonidas Donskis (Bauman and Donskis 2013:9-11). It opens the individual to the other, by promoting a "radically open hospitality" (Chow 2014:82) that exists primarily in and through the body.

In the era of Trump, our resistant politics demands this kind of friendship more than ever. It is of course true that the contemporary Left must work together to resist and overcome Trump and the populist Right he represents. What wrestling models is bow we can work together, perhaps better than many other performance forms, because it shows us how friendship can be practiced across identities and investments. Or even how friendship can be practiced without "liking." As Chow argues in "Work' and 'Shoot," the embodied work of wrestling, often described by wrestlers themselves as a "language," historically enabled physical intersubjective exchange to take place outside of "identity" (2014:83). In the absence of shared verbal language, a Japanese wrestler and a Mexican wrestler will nonetheless be able to work together to play and improvise a match. Thus, despite (or perhaps because of) the very real exploitation of wrestling bodies by the promoters or corporate owners, wrestling might be seen as a site of multiple solidarities, or what Leela Gandhi calls "affective communities" (2006) — between, for example, the immigrant worker and his American comrade/opponent. Or take also R. Tyson Smith's consideration of "passion work" in professional wrestling, where "performers jointly perform emotional labor in a high-stakes context where there is great risk for pain, injury or death" (2008:159). Furthermore, as oral histories (such as Simon Garfield's The Wrestling [2007]) and testimonies from British professional wrestlers demonstrate, the "friendship" we articulate here does not actually require any warm feelings or positivity (the history of pro wrestling, in Britain, in Japan, in Mexico, Puerto Rico, everywhere, is full of petty grudges and arguments). Indeed, two wrestlers can be in direct interpersonal conflict outside the ring, yet in the ring practice care and responsibility to the other. Mazer calls this "collusion," but we argue it provides a powerful model for solidarity and collaboration in the face of tremendous political challenges. At a time when the fractured Left debates "identity politics or economics" wrestling shows us a way to say "both, and."

\section{Wrestling, and Hopeful Gender and Race Politics}

To understand wrestling, you have to consider it as a diverse and global performance form.

As Mazer notes, professional wrestling (like politics, like the academy, like theatre and performance, historically) has often had extremely dubious gender politics. There is no doubt about this, as Mazer confirms in her reading of Miss Elizabeth's contribution to the Hogan/Savage storylines from 1988 and 1989 (2017b:17 [2018:191]). But, we suggest, the changing history of professional wrestling actually challenges the misogyny of current politics; indeed, Ben Litherland and Rachel Wood go as far as to say in their recent study that professional wrestling might actually offer a "critical feminist hope" (2017). But how can this possibly be true in a performance form with a history of bra-and-panties matches, when wrestling crowds have shouted "puppies" at female wrestlers? Mazer claims "even when women are wrestling, the subject is men and masculinity" (2017b:6 [2018:180]). How could this popular 
culture form provide, in Ernst Bloch's term, "militant optimism" in our contemporary world? ([1954] 1986:201).

We make the provocative claim that reading Trump's presidency through the gender politics of professional wrestling actually, and rather surprisingly, acts as a significant challenge to current political narratives. In the past few years, women have finally become prominent artists in professional wrestling, but they certainly were not absent from the form throughout its history. The recent Sisterbood of the Squared Circle: The History and Rise of Women's Wrestling (Laprade and Murphy 2017) has many, many examples of women participating and indeed leading the form from its inception in the 19th century to today. Many women-Mildred Burke, Mae Young, the Fabulous Moolah, Wendi Richter, Trish Stratus, Chyna, Lita-have played significant, transformative roles in professional wrestling history. However, during the Attitude Era (the WWE-era from the late-1990s on which Mazer focuses) women performers indeed became sexualized objects, their matches short, soft-porn interludes on cards dominated by men. (Although, even then, women often held their own in various storylines. Consider Trish Stratus's revenge on Vince McMahon at Wrestlemania X-Seven in 2001 after being sexually humiliated by McMahon.) To examine only the Attitude Era, it seems that the gender politics of professional wrestling are often as troubling as those in the recent election. Trump's claims to "grab women by the pussy" and his dismissive response to Clinton as a "Nasty Woman" indeed seem to come straight out of Attitude Era wrestling, as Mazer notes.

But in the contemporary era, the rise of women's wrestling, we claim, provides the sort of “militant optimism” Bloch demands. Professional wrestling is not, returning to Mazer's article, "above all, about men and masculinity" any more (2017b:6 [2018:180]). This is certainly true in the WWE, which, partly under the leadership of Vince McMahon's daughter, Stephanie McMahon, ditched the regrettably named Diva's Title and returned to the Women's Title. Since the brand split in 2016, WWE has maintained two women's belts: one for RAW and one for Smackdown Live. While there are still not as many women's matches as men's, women now headline pay-per-views (Sascha Banks v Charlotte at 2016 Hell in a Cell) and, most recently, WWE launched the Mae Young Classic, a tournament for women wrestlers from across the world. The final, between Shayna Bazler and Kairi Sane proved that the new generation of women wrestlers often have a real martial arts background and often come from diverse racial and ethnic backgrounds.

But this change is not reserved for the WWE. In the 1980s, GLOW attracted a new audience to women's wrestling and, while Japan has always had a strong history of women's wrestling (as Keiko Aiba discusses in her chapter in Performance and Professional Wrestling [2017]), and the figure of the luchadora exerts a longstanding presence in Mexican lucha libre, the US and the UK are finally catching up. Shimmer Wrestling was established in Chicago in 2005 as "a promotion that puts the focus on the actual wrestling ability of the women involved" (Shimmer Wrestling 2017). Pro-Wrestling:EVE, the self-proclaimed "feminist-punk-rock wrestling promotion" has taken London by storm (EVE 2017; Phillips 2017). Progress, one of the UK's most innovative wrestling companies, launched its women's belt in 2017; Insane Championship Wrestling established its own belt the previous year.

While, like other representational forms, there is no doubting wrestling's troublesome gender history, today professional wrestling does not, returning to Mazer's description, "Forget feminism" (2017b:17 [2018:192]). Nor can we agree that "Femininity, femaleness itself, is 
perceived as an essential affront to the ethos of male honor" (17). Instead, recent changes in professional wrestling - the prominence of women performers, the establishment of women's promotions, the much-touted WWE "Women's Revolution"-actually give hope for change. Comparing Trump's presidency to wrestling in the past could actually be a highly fruitful approach, but only if read through the dramatic changes in women's wrestling since then. If we do this then Trump's narrative feels as old fashioned as Hulk Hogan and Randy Savage, long overtaken by new gender narratives. It feels obsolete, out of step with accepted opinion, something to be confined to the past.

In very similar ways, re-emerging narratives of white supremacism are one of the most shocking elements of the new political regime. And, just as with gender politics, wrestling could be seen as contributing to such narratives, a fact we made clear with a provocative section on race in Performance and Professional Wrestling. Charles Hughes's analysis of "racial violence as a narrative and performative tactic" still contains the capacity to shock the reader (2017:166). However, as with gender, to read Trump's presidency through contemporary wrestling, rather than statically compare it to three decades ago is to find new hope for challenging the rise in race hate. While the typical foreign invader is still a present figure in the WWE, Jinder Mahal (a Canadian of Indian descent) has had a long run as the WWE Champion, lately challenged not by a white American but by Japanese Shinsuke Nakamura. Sami Zayn, current WWE wrestler, has used his profile to help set up a clinic in Syria; the current WWE tag team champions are the New Day, and, while their initial gimmick relied heavily on African American stereotypes (namely a fervent call-and-response preaching style), their overwhelming popularity and ability to reshape their characters are testament to the malleable nature of the form and the possibilities of enacting and reacting to larger social and cultural narratives. When the WWE gets it wrong, wrestling fans are far more critical than Mazer's article might suggest. Jinder Mahal's recent scripted mocking of Nakamura that relied heavily on racist tropes, for example, was met with boos from WWE fans in Oakland with one 15-year-old fan telling the Washington Post, "racism is definitely an idiotic way to get heat and not necessary" (in Payne 2017). Trump, take heed! Dave Melzer, a well-respected journalist who has covered professional wrestling throughout his career, provided another analysis of this storyline:

People are different, the product is different and society is different [...] You look at stuff that was done even 15-20 years ago, and a large percentage of it, you'd go, you could never do that now. I see this reaction as another example as to why they'll [WWE] be careful not to do it again. (in Payne 2017)

No doubt in its attempt to find heat in its storylines the WWE (and other products) will perhaps continue to make unpardonable errors. Yet, contemporary wrestling (even the WWE) has moved well away from the days of black slave characters and white all-American, unbeatable faces that Hughes describes in such horrifying detail in Performance and Professional Wrestling. Again, here the shifting history of professional wrestling challenges the narratives of white supremacism that have frightened so many following American politics over the past year.

Wrestling is an international spectacle, enjoyed by fans across the world. Few forms of performance or popular culture have transcended national borders as wrestling has. Japan, as Aiba notes in her chapter for Performance and Professional Wrestling, has a tremendous history of wrestling (especially women's wrestling). Mexico too, as Heather Levi has noted in her 
pathbreaking scholarship, has its own wrestling style with an illustrious history (2008). In recent years WWE has played live shows in countries such as China and Saudi Arabia, and presents its shows in a variety of languages including Spanish, Mandarin, and Arabic. In the past year, the WWE has named its first Chinese wrestler, Bin Wang, and, shattering a number of current political taboos and tensions, its first woman wrestler from the Arab world, Jordanian Shadia Bseiso. While clearly these are partly economic decisions, they are also testimony to professional wrestling's popularity across the globe, and its potential ability to counteract the isolationist, fearful rhetoric of current American politics.

\section{Conclusion}

Towards the close of "Donald Trump Shoots the Match," Sharon Mazer writes, "if Donald Trump is shooting the match in the White House, much as he did in the squared circle, then the obvious question is: who is the Vince McMahon, the money man who owns the game and directs the players for the entertainment of the punters" (2017b:20 [2018:195])? With the current intensification of Robert Mueller's investigation, the tempting answer is, of course, "Russia." But the real answer-one that we think Mazer herself knows and hints at - is "all of us." While Vince McMahon is indeed a real person who is Chairman and CEO of World Wrestling Entertainment, Inc., he is also a gimmick, a character called "Mr. McMahon," whose supposed "control" over the game is, to a large extent, a work. Wrestling, like democratic politics, is a participatory form, and McMahon's performance of power is dependent on audiences' collective agreement to keep kayfabe, to maintain the illusion of it. Through the history of wrestling, there are numerous examples of audiences exerting their power to change the narrative, turn a face into a heel, or crown a champion (see Eero Laine's analysis of the "Yes Movement" that coalesced around Daniel Bryan's fans in 2013-14 [2017] and Claire Warden's writings on the power of audience silence [2017]). Wrestling's collectively maintained illusion is like politics - we want to blame it all on someone with more money and power, but ultimately, change is possible.

The issue is what we do with this knowledge. In "Epilogue: The Game of Life," Mazer clearly details this tension:

The true tension is between the cynicism that tells us it's all a game owned by the guy with the money at the expense of the rest of us, and the optimism that keeps us in, keeps us trying to find a way to be more smart than mark, and barring that, at least to acquire the self- and social-awareness to see how we are made into marks, and with that knowing to learn to act outside the box, to break free of the squared circle, of its ethos and of the dominant culture pro wrestling so richly represents. (2017a:204)

But the problem is, there is no outside of the squared circle, since the ring, the game, is life itself. Mazer's passionate condemnation of Trump seems to be a despairing howl at the discovery of this fact. Considering the horrorshow of Trump's first year in office, pessimism seems appropriate. What we have proposed throughout this response essay is that wrestling offers hope and optimism, a way of seeing and, more importantly, acting, that is critical and transformative.

Even though there may be nothing outside the squared circle, wrestling shows us that we can still transform what goes on inside. The sudden burst of interest in pro wrestling since Trump's election should not be taken as an indication that politics, the media, and reality itself are 
becoming more like wrestling, but rather as a recognition that things have always been like wrestling. In this context, the idea of wrestling "work," usually taken to mean "con" or deception, might be taken as a powerful guiding principle that though reality is no more fake than the scars borne on wrestlers' bodies, it is transformable. Donald Trump may be shooting the match, but we can still work it.

\section{References}

Aiba, Keiko. 2017. "The impact of women's pro wrestling performances on the transformation of gender.” Translated by Minata Hara. In Performance and Professional Wrestling, edited by Broderick Chow, Eero Laine, and Claire Warden, 85-94. London: Routledge.

Ball, Michael R. 1990. Professional Wrestling as Ritual Drama in American Popular Culture. Lewiston, NY: Edwin Mellen Press.

Bateman, Oliver Lee. 2016. "Wrestling, Politics, and the Violent Realities of 2016." Pacific Standard, 22 December. Accessed 23 December 2017. https://psmag.com/news/wrestling-politics-and-the-violent-realities-of-2016.

Bauman, Zygmunt, and Leonidas Donskis. 2013. Moral Blindness: The Loss of Sensitivity in Liquid Modernity. Cambridge, UK: Polity Books.

Bloch, Ernst. (1954) 1986. The Principle of Hope. Vol. 1. Translated by Neville Plaice, Stephen Plaice, and Paul Knight. Cambridge, MA: The MIT Press.

Brecht, Bertolt. (1926) 1964. "Emphasis on Sport." In Brecht on Theatre: The Development of an Aesthetic, edited and translated by John Willet, 6-9. New York: Hill and Wang.

Chow, Broderick D.V. 2014. "Work and Shoot: Professional Wrestling and Embodied Politics." TDR 58, 2 (T222):72-86.

Chow, Broderick, Eero Laine, and Claire Warden, eds. 2017. Performance and Professional Wrestling. London: Routledge.

de Garis, Laurence. 1999. "Experiments in Pro Wrestling: Toward a Performative and Sensuous Sport Ethnography." Sociology of Sport Iournal 16, 1:65-74.

Di Benedetto, Stephen. 2017. "Playful engagements: Wrestling with the attendant masses." In Performance and Professional Wrestling, edited by Broderick Chow, Eero Laine, and Claire Warden, 26-36. London: Routledge.

EVE. 2017. Pro-Wrestling:EVE. Accessed 6 November. http://www.evewrestling.com.

Ezell, Jon. 2017. "The dissipation of 'heat': Changing role(s) of audience in professional wrestling in the United States." In Performance and Professional Wrestling, edited by Broderick Chow, Eero Laine, and Claire Warden, 9-16. London: Routledge.

Ford, Sam. 2018. “He's a Real Man's Man': Pro Wrestling and Negotiations of Contemporary Masculinity." The Routledge Companion to Media Fandom, edited by Melissa A. Click and Suzanne Scott, 174-83. London: Routledge. 
Gandhi, Leela. 2006. Affective Communities: Anticolonial Thought, Fin-de-Siècle Radicalism, and the Politics of Friendship. Durham, NC: Duke University Press.

Garfield, Simon. 2007. The Wrestling. London: Faber \& Faber.

Gilpin, Betty. 2017. “Glow Star Betty Gilpin: What It’s Like to Have Pea-Sized Confidence with Watermelon-Sized Boobs." Glamour, 23 June. Accessed 1 November. https:/www.glamour.com/story/glow-star-betty-gilpin-what-its-like-to-have-pea-sizedconfidence-with-watermelon-sized-boobs.

Gordon, Jeremy. 2016. “Is Everything Wrestling?” New York Times, 27 May. Accessed 15 February 2018. www.nytimes.com/2016/05/27/magazine/is-everything-wrestling.html.

Hadley, Jamie Lewis. 2017. "The hard sell: The performance of pain in professional wrestling." In Performance and Professional Wrestling, edited by Broderick Chow, Eero Laine, and Claire Warden, 154-62. London: Routledge.

Halberstam, Judith (Jack). 2011. The Queer Art of Failure. Durham, NC: Duke University Press.

Hedges, Chris. 2009. Empire of Illusion: The End of Literacy and the Triumph of Spectacle. New York: Nation Books.

Hughes, Charles. 2017. “Tell them it's what their grandfathers got': Racial violence in southern professional wrestling." In Performance and Professional Wrestling, edited by Broderick Chow, Eero Laine, and Claire Warden, 165-76. London: Routledge.

Jenkins, Henry. 1992. Textual Poachers: Television Fans and Participatory Culture. London: Routledge.

Laine, Eero. 2017. "Stadium-sized theatre: WWE and the world of professional wrestling." In Performance and Professional Wrestling, edited by Broderick Chow, Eero Laine, and Claire Warden, 39-47. London: Routledge.

Laprade, Pat, and Dan Murphy. 2017. Sisterhood of the Squared Circle: The History and Rise of Women's Wrestling. Toronto: ECW Press.

Levi, Heather. 2008. The World of Lucha Libre: Secrets, Revelations, and Mexican National Identity. Durham, NC: Duke University Press.

Litherland, Ben, and Rachel Wood. 2017. "Critical Feminist Hope: The Encounter of Neoliberalism and Popular Feminism in WWE 24: Women's Evolution." Feminist Media Studies, 3 November. Accessed 20 February 2018. https://www.tandfonline.com/doi/full/10.1080/14680777.2017.1393762.

Mazer, Sharon. 1990. “The Doggie Dog World of Professional Wrestling.” TDR 34, 4 (T128):96-122.

Mazer, Sharon. 1998. Professional Wrestling: Sport and Spectacle. Jackson: University Press of Mississippi.

Mazer, Sharon. 2017a. "Epilogue: The Game of Life." In Performance and Professional Wrestling, edited by Broderick Chow, Eero Laine, and Claire Warden, 196-206. London: Routledge. 
Mazer, Sharon. 2017b. “Donald Trump Shoots the Match.” TDR, 7 September. Accessed 6 November 2017. https://doi.org/10.1162/DRAM_a_00713.

Mazer, Sharon. 2018. “Donald Trump Shoots the Match.” TDB 62, 2 (T238):175-200.

Morton, Gerald W., and George M. O'Brien. 1985. Wrestling to Rasslin': Ancient Sport to American Spectacle. Bowling Green, OH: Bowling Green University Popular Press.

Nevitt, Lucy. 2010. “The Spirit of America Lives Here': US Pro-Wrestling and the Post-9/11 "War on Terror." Lournal of War and Culture Studies 3, 3:319-34.

Payne, Marissa. 2017. "WWE Has Dealt with Racism before but a Scripted Rant Has Fans Chanting 'That's Too Far!"' The Washington Post, 20 September. Accessed 6 November 2017. www.washingtonpost.com/news/early-lead/wp/2017/09/20/wwe-has-dealt-withracism-before-but-a-scripted-rant-has-fans-chanting-thats-toofar/?utm_term=.a133b967e7f6.

Phillips, Tom. 2017. "Britain's Real Female Wrestler Activists Are Better and Badder than GLOW's Could Ever Be." The Conversation, 7 July. Accessed 6 November. http://theconversation.com/britains-real-female-wrestler-activists-are-betterand-badder-than-glows-could-ever-be-80643.

Rahilly, Lucia. 2005. "Is $R A W$ War?: Professional Wrestling as Popular S/M Narrative." In Steel Chair to the Head: The Pleasure and Pain of Professional Wrestling, edited by Nicholas Sammond, 213-31. Durham, NC: Duke University Press.

Ridout, Nicholas, and Rebecca Schneider. 2012. "Precarity and Performance: An Introduction." TDR 56, 4 (T216):5-9.

Sammond, Nicholas. 2005. "Introduction: A Brief and Unnecessary Defense of Professional Wrestling." In Steel Chair to the Head: The Pleasure and Pain of Professional Wrestling, edited by Nicholas Sammond, 1-22. Durham, NC: Duke University Press.

Shimmer Wrestling. 2017. "FAQ." Accessed 6 November. www.shimmerwrestling.com/p/faq.html.

Smith, R. Tyson. 2008. "Passion Work: The Joint Production of Emotional Labor in Professional Wrestling." Social Psychology Ouarterly 71, 2:157-76.

Smith, R. Tyson. 2014a. Fighting for Recognition: Identity, Masculinity, and the Act of Violence in Professional Wrestling. Durham, NC: Duke University Press.

Smith, R. Tyson. 2014b. "Playing the Role of Jobber." ChronicalVitae, 19 September. Accessed 2 March 2018. https://chroniclevitae.com/news/713-playing-the-role-of-jobber.

Warden, Claire. 2017. "Pops and promos: Speech and silence in professional wrestling." In Performance and Professional Wrestling, edited by Broderick Chow, Eero Laine, and Claire Warden, 17-25. London: Routledge.

Ware, Nicholas. 2017. "Wrestling's not real, it's hyperreal: Professional wrestling video games." In Performance and Professional Wrestling, edited by Broderick Chow, Eero Laine, and Claire Warden, 48-56. London: Routledge. 
World Wrestling Entertainment (WWE). 2017. “Donald Trump.” Accessed 1 November 2017. www.wwe.com/superstars/donald-trump.

Wrenn, Marion. 2007. "Managing Doubt: Professional Wrestling Jargon and the Making of 'Smart Fans'.' In Practicing Culture, edited by Craig Calhoun and Richard Sennett, 149-70. London: Routledge.

ClaireWarden, Loughborough University claire.warden@dmu.ac.uk

Broderick Chow, Brunel University London broderick.chow@brunel.ac.uk

Eero Laine, University at Buffalo, State University of New York eerolain@buffalo.edu 


\title{
Sharon Mazer Responds to Warden, Chow, and Laine
}

\author{
As the wrestlers in Mazer's study become characters in a narrative about the relationship between \\ performance and culture, so too does Mazer become a character in my conceptual discussion of the \\ relationship between sensuous experiences and textual representations. —Laurence de Garis (2010:946)
}

"Working Loose" landed in my inbox a week ago. Its authors are scholars on the rise, with whom I have been in various conversations for several years, and whose writing on professional wrestling I have read with interest: Warden on the role of the "speech act" in the construction of the spectacle (2017); Laine on the intrinsic theatricality of the game (2017); and Chow's parsing of the difference between "collusion" and "cooperation" (2014). They graciously invited me to contribute an epilogue to their coedited Performance and Professional Wrestling (2017), and we've had cheerful chats about "smarks" and kayfabe. And I am currently collaborating with Eero Laine and two other colleagues to edit a collection of essays tentatively titled Professional Wrestling: Politics and Populism (forthcoming 2019). As such, one might expect this "Response" to be a "work," a set-up to generate academic heat in an overheated field. We might be colluding. Or if "collude" seems too pejorative a word, perhaps we are engaging in a collegial performance concocted in order to reach a wider audience. But this isn't that. Their response to my essay arrived without advance discussion. Its language is too heated to be the sort of serious play that often underlies such exchanges, and its drive and tone sound more like that of an academic smackdown — or really, the fervent squabbling of fans ringside. Who is smart? Who the mark? Who is working? Who shooting?

In attacking the ethos of my performance ethnography, Chow, Laine, and Warden look to Laurence de Garis for backup. In particular, they lean on his early article, "Experiments in Pro Wrestling: Toward a Performative and Sensuous Sport Ethnography" (1999), which is based in large part on a paper he delivered to great effect (he told me afterward) at a Sociology of Sport conference a few years prior. Their reading is surprisingly literal for professional wrestling scholars. They cherry-pick his critical statements and latch onto his conclusion that I lacked the kind of knowledge that could be gained from what he terms a more "sensuous" ethnographic engagement. There is a profound truth here, one I have readily acknowledged, most directly in "Watching Wrestling / Writing Performance" (2002). Our differing stances yielded different understandings, de Garis explicitly recognizes, both in his 1999 article and in the one that followed: "Sometimes a bloody nose is just a bloody nose: Play and contest in boxing, wrestling, and ethnography" (2010).

Thing is, this apparently combative tour de force was itself an experiment in ethnography that began when de Garis and I met at Gleason's Arena in the late 1980s. It was a work. We were both in graduate school, both looking for an angle, both career-building, both looking for jobs. Early on, we agreed to become characters in each other's ethnographic narratives. As Larry Brisco, he took a prominent role in my early writing about professional wrestling; at the same time, Laurence de Garis was creating a persona for me as a foil. The Sociology of Sport paper drew heat; listeners were outraged and defensive on his behalf. I took the bump for him, allowing

TDR: The Drama Review 62:2 (T238) Summer 2018. (02018 New York University and the Massachusetts Institute of Technology 
myself - not untruthfully - to be represented as a rather unwitting, non- (or only marginally) participant ethnographer so that he could claim victory as the wrestler/object talking back.

His articles, as well as my own publications, were set against the backdrop of the texts we were reading at that time, particularly critiques of Clifford Geertz's "Balinese Cockfight" (1973). ${ }^{1}$ For us it was a form of play, not so deep perhaps, but serious enough-a way of testing our ideas in the academic arena. We were telling two sides of the same stories, balancing truth with craft, creating the appearance of conflict, because sometimes a difference of opinion is more generative than making nice. We were performing for audiences-academicswho weren't in on the conversation we were having, theatricalizing our positions in order to get ahead in a highly competitive marketplace, being smart about the unwritten rules of the academic game. We were doing a job to get a job. It worked. Rereading the articles now, I am again struck by how rigorously reasoned Larry's takedown of my performance ethnography is, and how graceful.

On the surface, "Working Loose: A Response to "Donald Trump Shoots the Match" might seem much the same. The writers begin with a quick walk through my article's basic points as they see them, then devolve rather quickly into a three-pronged attack, roughly accusing me of: antitheatrical prejudice and underestimating the audience's agency; of maintaining privilege and promulgating misunderstanding by not getting into the ring; and failing to reckon with the changing role of women in the game. They say: "Her analysis of wrestling and politics concludes that fans/voters were 'duped' by Trump, that he has 'converted his fans into voters"' (2018:202). The second half of this sentence contains a direct quote from my article: the first, in spite of its deployment of quote marks, does not. Their defense of wrestling fans/Trump voters soon begins to echo Trump's own "To me, they look like a very smart group of people" (in WWE 2013), but (unlike Mr. McMahon) I never said the fans/ voters weren't.

It is unfortunate that the authors' criticism is so personally pointed:

[...] a larger problem is her claim to ownership over academic studies of professional wrestling, and the way that her critical position precludes any knowledge beyond a traditionally academic knowledge (and, it seems, any knowledge beyond her own). (2018:202)

In fact, my claim is to be the first theatre and performance scholar to study professional wrestling, and one of my key findings almost 30 years ago was that fans are more "smart" than "mark." The authors pitch "Mazer's flat condemnation of professional wrestling's complicated mix of theatricality and performance, deceit and truth" against their "suggest[ion] that professional wrestling is a means for fans and wrestlers alike to think critically about contemporary politics and the state of the world" (2018:202). But one of my primary points, beginning with my first article in TDR (1990) is that professional wrestling is a highly theatrical, popular performance practice that offers us significant insights into contemporary political and social realities that otherwise might go unremarked. And so on.

1. Chiefly: Clifford and Marcus, Writing Culture (1986) and Crapanzano, Hermes' Dilemma and Hamlet's Desire (1992). 
Ironically, I think their fighting words are largely unnecessary. Their research, observations, analyses, and arguments are powerful enough to stand on their own, individually and collectively, without setting me up as a straw (wo)man, as a rather naïve jobber in contrast to their displays of virtuous virtuosity. They cast me as a condescending cultural elitist; themselves (like Trump) as the defenders both of wrestlers and fans, and of the voters. I am a mark; they are smart. They want to see the play between wrestlers and fans as an opening for real political debate and change; I see it more as a symptom of realpolitik, more static and less dynamic, deceptive for the way it feels like we're breaking through when often as not we're circling back. They reach the same conclusion, but are hopeful where I am not: "Donald Trump may be shooting the match, but we can still work it" (2018:212). But who is this "we"? It may be that this contest is more generational than academic. Regardless, if I am to find hope in the face of despair, I see it in the eloquent grief-stricken rage of the Florida students and parents who are forcing Trump and other politicians, the media and pundits, to re-examine their scripts (see Davis 2018). That Trump still couldn't do the job, even with a cue card in hand, is simply another case in point.

-22 February 2018

References

Chow, Broderick D.V. 2014. "Work and Shoot: Professional Wrestling and Embodied Politics." TDR 58, 2 (T222):72-86.

Chow, Broderick, Eero Laine, and Claire Warden, eds. 2017. Performance and Professional Wrestling. London: Routledge.

Clifford, James, and George E. Marcus, eds. 1986. Writing Culture: The Poetics and Politics of Ethnography. Berkeley: University of California Press.

Crapanzano, Vincent. 1992. Hermes' Dilemma and Hamlet's Desire: On the Epistemology of Interpretation. Cambridge, MA: Harvard University Press.

Davis, Julie Hirschfeld. 2018. "Parents and Students Plead with Trump: 'How Many Children Have to Get Shot?” New York Times, 21 February. Accessed 22 February 2018. www.nytimes.com/2018/02/21/us/politics/trump-guns-school-shooting.html.

de Garis, Laurence. 1999. "Experiments in Pro Wrestling: Toward a Performative and Sensuous Sport Ethnography." Sociology of Sport Iournal 16, 1:65-74.

de Garis, Larry. 2010. "Sometimes a bloody nose is just a bloody nose: Play and contest in boxing, wrestling, and ethnography." Sport in Society 13, 6:935-51.

Geertz, Clifford. 1973. "Deep Play: Notes on the Balinese Cockfight." Interpretation of Cultures, 412-53. New York: Basic Books.

Laine, Eero. 2017. "Stadium-sized theatre: WWE and the world of professional wrestling." Performance and Professional Wrestling, eds. Broderick Chow, Eero Laine, and Claire Warden, 39-47. London: Routledge.

Mazer, Sharon. 1990. “The Doggie Doggie World of Professional Wrestling.” TDR 34, 4 (T128):96-122. 
Mazer, Sharon. 2002. "Watching Wrestling / Writing Performance." Hop on Pop: The Politics and Pleasures of Popular Culture, eds. Henry Jenkins, Tara McPherson, and Jane Shattuc, 270-86. Durham, NC: Duke University Press.

Mazer, Sharon. 2018. "Donald Trump Shoots the Match.” $\underline{T D R}$ 62, 2 (T238). https://doi/abs/10.1162/DRAM_a_00713.

Warden, Claire. 2017. "Pops and promos: Speech and silence in professional wrestling." Performance and Professional Wrestling, eds. Broderick Chow, Eero Laine, and Claire Warden, 17-25. London: Routledge.

Warden, Claire, Broderick Chow, and Eero Laine. 2018. "Working Loose: A Response to 'Donald Trump Shoots the Match' by Sharon Mazer.” TDR 62, 2 (T238):201-215. https://doi/abs/10.1162/DRAM_c_00764.

WWE. 2013. "Mr. McMahon and Donald Trump's Battle of the Billionaires Contract Signing." YouTube, 8 December 2013. Accessed 8 May 2017. www.youtube.com/watch?v=vVeVcVBW_CE. 
This article has been cited by:

1. Sharon Mazer. 2018. Donald Trump Shoots the Match. TDR/The Drama Review 62:2, 175-200. [Abstract] [PDF] [PDF Plus] 2. 2018. Sharon Mazer Responds to Warden, Chow, and Laine. TDR/The Drama Review 62:2, 216-219. [Citation] [PDF] [PDF Plus] 